Notre Dame Law Review

Volume 91 | Issue 3

Article 1

4-2016

\title{
Originalist or Original: The Difficulties of Reconciling Citizens United with Corporate Law History
}

Leo E. Strine Jr.

Delaware Supreme Court

Nicholas Walter

Wachtell, Lipton, Rosen \& Katz

Follow this and additional works at: http://scholarship.law.nd.edu/ndlr

Part of the Constitutional Law Commons, and the Supreme Court of the United States Commons

\section{Recommended Citation}

91 Notre Dame L. Rev. 877 (2016)

This Article is brought to you for free and open access by the Notre Dame Law Review at NDLScholarship. It has been accepted for inclusion in Notre Dame Law Review by an authorized administrator of NDLScholarship. For more information, please contact lawdr@nd.edu. 
ARTICLES

\title{
ORIGINALIST OR ORIGINAL: THE DIFFICULTIES OF RECONCILING CITIZENS UNITED WITH CORPORATE LAW HISTORY
}

\author{
Leo E. Strine, Jr. * E Nicholas Walter**
}

\section{INTRODUCTION}

Much has and will continue to be written about the United States Supreme Court's decision in Citizens United v. FEC. ${ }^{1}$ In that decision, the Court held that the part of the Bipartisan Campaign Reform Act of 2002 (the

(C) 2016 Leo E. Strine, Jr. \& Nicholas Walter. Individuals and nonprofit institutions may reproduce and distribute copies of this Article in any format at or below cost, for educational purposes, so long as each copy identifies the author, provides a citation to the Notre Dame Law Review, and includes this provision in the copyright notice.

* Chief Justice, Delaware Supreme Court; Adjunct Professor, University of Pennsylvania Law School; Austin Wakeman Scott Lecturer, Harvard Law School; Senior Fellow, Harvard Program on Corporate Governance; Adjunct Professor, Vanderbilt University School of Law; Henry Crown Fellow, Aspen Institute.

** Associate, Wachtell, Lipton, Rosen \& Katz. The authors are grateful for the invaluable assistance of Elane Boulden, Andrew Berni, Dorothy Shapiro, and Sonia Steinway, and for helpful comments from Bill Allen, Bill Bratton, Bill Budinger, Robert Clark, Jill Fisch, Ronald Gilson, Jeff Gordon, Joe Grundfest, Larry Hamermesh, Jonathan Lipson, Ian Nussbaum, Miguel Padro, Alan Palmiter, Ed Rock, Lynn Stout, and Eric Talley.

1558 U.S. 310 (2010). For a review of the literature spawned by Citizens United, see generally Robert C. Post, Citizens Divided: Campaign Finance Reform and the Constitution (2014); Leo E. Strine, Jr. \& Nicholas Walter, Conservative Collision Course?: The Tension Between Conservative Corporate Law Theory and Citizens United, 100 CoRnell L. Rev. 335 (2015). Various authors have briefly criticized Citizens United in originalist terms. See, e.g., Joseph F. Morrissey, A Contractarian Critique of Citizens United, 15 U. PA. J. Const. L. 765 , 780-84 (2013) (criticizing Justice Scalia's originalism); Geoffrey R. Stone, Citizens United and Conservative Judicial Activism, 2012 U. ILL. L. REv. 485, 497 ("[A]ny Justice attempting seriously to employ an originalist analysis in Citizens United would also have had to uphold the legislation."); Amanda D. Johnson, Comment, Originalism and Citizens United: The Struggle of Corporate Personhood, 7 Rutgers Bus. L.J. 187 (2010). We provide a comprehensive critique. The most detailed treatments of this topic of which we are aware are Ruth $\mathrm{H}$. Bloch \& Naomi R. Lamoreaux, Corporations and the Fourteenth Amendment (2014) (unpublished manuscript) (on file with author), and Ian Speir, Corporations, the Original Understanding, and the Problem of Power, 10 Geo. J.L. \& Pub. Pol'y 115, (2012). As the title of 
"McCain-Feingold Act") that prohibited corporations from making expenditures expressly in favor of the election or defeat of political candidates, except through corporate-sponsored political action committees that raised specific funds for that purpose, was unconstitutional as applied to the nonprofit advocacy corporation before the Court. ${ }^{2}$ In its sweeping ruling, the Court suggested that the managers of even for-profit corporations whose shares are publicly traded have a First Amendment right to spend unlimited amounts of treasury funds to influence the political process, including to advocate the election or defeat of particular candidates for office.

In this Article, we focus on a specific question raised by Citizens United, which is whether the Supreme Court's decision can be justified solely by application of the originalist method of constitutional interpretation, or whether it can only be explained by giving substantial weight to a more modern, evolved understanding of the relevant constitutional provisions. The dissent in Citizens United, authored by Justice Stevens and joined by Justices Ginsburg, Breyer, and Sotomayor, argued that the decision could not be defended on originalist grounds. In Justice Stevens's view, the Framers "had little trouble distinguishing corporations from human beings, and when they constitutionalized the right to free speech in the First Amendment, it was the free speech of individual Americans that they had in mind." 3 In a concurring opinion, originalist Justice Scalia, joined by Justice Alito and in relevant part by Justice Thomas, claimed that the majority's result was faithful to originalism as they articulate it. ${ }^{4}$ Justice Scalia argued that there was no historical evidence that the government could restrict the speech of business corporations.

In addressing this subject, we acknowledge that Justices Scalia and Alito concurred in the majority opinion, an opinion that itself did not rely upon the originalist methodology, and that the originalist concurrence was crafted as a rebuttal to Justice Stevens's dissent, which argued that the majority opinion was unhistorical. Nevertheless, because Justices Scalia and Thomas, and originalist methodology, have such influence in current jurisprudence, we believe it is important to consider whether Citizens United can be rationalized on originalist grounds. After all, originalists claim that their method is the only method faithful to the idea that the law is something determinable as the work of certain legitimately empowered authorities, and not whatever the current group of judges decides to say it is.

their excellent essay suggests, Bloch and Lamoreaux focus on developments in the 1860s and after. Our analysis starts earlier, but we are indebted to them.

2 See 2 U.S.C. $\$ 441 b(a)$ (2006) ("It is unlawful for . . a any corporation . . . or any labor organization, to make a contribution or expenditure in connection with any [federal] election ... or in connection with any primary election or political convention or caucus held to select candidates for any of the foregoing offices . . . .”).

3 Citizens United, 558 U.S. at 428 (Stevens, J., dissenting).

4 Id. at 385-93 (Scalia, J., concurring). 
Originalism is an interpretive doctrine commonly associated with those who describe themselves as conservative. ${ }^{5}$ In a prior article, we discussed whether Citizens United, usually seen as a product of the "conservative" wing of the Supreme Court, could be reconciled with the predominant conservative corporate law theory, and found that it could not. ${ }^{6}$ In this Article we explore whether the outcome in Citizens United can be justified by reference to the originalist interpretive principles as embraced by Justice Scalia and other prominent conservatives. ${ }^{7}$

Originalist interpretation, as applied by Justice Scalia, entails a two-pronged approach. ${ }^{8}$ In the first instance, if the constitutional text is unambiguous and answers the question posed, the Court must give the text its unambiguous meaning. If, however, the text is ambiguous or does not directly address the question before the Court, then the Court is to do its best to interpret the text consistently with the understanding at the time of its adoption. Contemporaneous societal understanding is therefore what is relevant to originalists such as Justice Scalia, who eschew the notion of a "living constitution" whose meaning changes by virtue of changing societal norms and judicial interpretations rather than changes to constitutional text.

Here, we observe that the text of the First Amendment does not specifically address the question of whether business corporations have the right to make unlimited treasury expenditures advocating the election or defeat of political candidates. More broadly, we note that the Constitution does not indicate that entities created and chartered by authority of legislation, as opposed to actual human beings, have any free speech rights at all. ${ }^{9}$ We thus examine whether Citizens United can be rationalized as originalist by reference to the historical understanding of the legal status and social role of the business corporation-including its ability to exercise constitutional rightsas of two critical time periods. The first is 1789 to 1791 , when the First

5 It is, for example, associated with Robert Bork and Antonin Scalia. See infra Section II.A.

6 Strine \& Walter, supra note 1.

7 Originalism now has many variants, not all of them conservative. See, e.g., Cass R. Sunstein, Originalism for Liberals, New Republic (Sept. 28, 1998), https://newrepublic .com/article/64084/originalism-liberals (reviewing multiple works by Akhil Reed Amar). For example, Professor Balkin has written incisive works adopting a form of originalism that comes from a very different perspective. See Jack M. Balkin, Living Originalism (2011); Jack M. Balkin, Abortion and Original Meaning, 24 Const. Comment. 291 (2007); Jack M. Balkin, Original Meaning and Constitutional Redemption, 24 Const. Comment. 427 (2007).

8 See infra Section II.A.

9 The First Amendment provides that "Congress shall make no law respecting an establishment of religion, or prohibiting the free exercise thereof; or abridging the freedom of speech, or of the press, or the right of the people peaceably to assemble, and to petition the Government for a redress of grievances." U.S. Const. amend. I. Notably absent from this formulation (and the rest of the Constitution) is any mention of corporations, as distinguished scholars have pointed out. See, e.g., Charles R. O'Kelley, Jr., The Constitutional Rights of Corporations Revisited: Social and Political Expression and the Corporation After First National Bank v. Bellotti, 67 GEO. L.J. 1347, 1352 (1979). 
Amendment was submitted to the states and became part of our nation's Constitution. The second is 1866 to 1868, when the Fourteenth Amendment was added to the Constitution. These periods are relevant because Citizens United suggests that the First Amendment gave rights to for-profit corporations in part by virtue of rulings treating business corporations as persons under the Fourteenth Amendment and entitled to raise certain constitutional rights against state intrusion by virtue of that Amendment. ${ }^{10}$

At each historical stage, we find that the relevant text is not clear that business corporations are entitled to First Amendment speech protection and that an originalist would have to consult historical context to determine whether that was so. As to the First Amendment, one of the first originalists, Robert Bork, wrote that " $[\mathrm{t}]$ he framers seem to have had no coherent theory of free speech and appear not to have been overly concerned with the subject." 11 As a result, "[w]e are . . f forced to construct our own theory of the constitutional protection of speech. We cannot solve our problems simply by reference to the text or to its history." 12 The text of the Fourteenth Amendment also provides no suggestion at all that corporations were considered "persons" for purposes of the Amendment.

When the historical public understanding of the First Amendment is considered, the originalist foundations of Citizens United begin to quiver. As of the Founding, there were no business corporations operating under socalled general corporation statutes. ${ }^{13}$ Rather, the only extant business corporations were specifically created by legislatures with detailed charters that their managers were obligated to follow with fidelity. The ultra vires doctrine forced corporations to strictly adhere to the powers, activities, and ends detailed in their charters. Someone with a much closer view to the historical context than any current Supreme Court Justice, ${ }^{14}$ the Chief Justice of the United States in 1819, wrote in his decision in the Dartmouth College case that "[a] corporation is an artificial being, invisible, intangible, and existing only in contemplation of law. Being the mere creature of law, it possesses only those properties which the charter of its creation confers upon it, either

10 Citizens United v. FEC, 558 U.S. 310, 342 (2010) (collecting cases applying the First Amendment to corporations).

11 Robert H. Bork, Neutral Principles and Some First Amendment Problems, 47 IND. L.J. 1, 22 (1971).

$12 I d$.

13 Susan Pace Hamill, From Special Privilege to General Utility: A Continuation of Willard Hurst's Study of Corporations, 49 Am. U. L. Rev. 81, 84 (1999).

14 When interpreting ambiguous constitutional text, we consider it a responsible act of modesty to give weight to the views of those closer in time to the text's adoption. Cf. Frank Easterbrook, Foreword, in Antonin Scalia \& Bryan A. Garner, Reading Law, at xxv (2012) ("Words don't have intrinsic meanings; the significance of an expression depends on how the interpretive community alive at the time of the text's adoption understood those words. The older the text, the more distant that interpretive community from our own. At some point the difference becomes so great that the meaning is no longer recoverable reliably."). 
expressly, or as incidental to its very existence." 15 As an originalist matter, therefore, it was impossible for the First Amendment to generally accord business corporations broad expressive rights because the understanding at the time was that corporations only had the rights specifically granted in their charters, and that corporations were not in any way persons like actual human beings. In fact, corporations had the opposite relationship to society as human beings in the Lockean-Jeffersonian sense, in that rather than possessing inalienable rights that society could not take away, corporations had only such rights as society explicitly gave them.

Likewise, as of the time of the adoption of the Fourteenth Amendment, there was no weakening of the accepted notion that corporations only had such rights as were specifically granted to them by the government that chartered them, and that they were subject to substantial governmental restriction. ${ }^{16}$ Although by that time, corporations had become more common and general corporation statutes had emerged allowing private citizens to form corporations consistent with the broader enabling nature of those statutes, the ultra vires doctrine (albeit somewhat weakened) remained the prevailing rule. ${ }^{17}$ Most important, legislatures that had moved to adopt general corporation statutes did so on the assumption that they reserved the power to restrict corporations from engaging in conduct inconsistent with the public interest. ${ }^{18}$ That is, corporations remained creatures of the state in the sense that they were granted a legal existence on the condition that they operate within the constraints imposed upon them by society. And as internal corporate law constraints weakened, other external sources of law emerged to address the influence of corporations, including laws restricting their involvement in the political process. Thus, the idea that corporations were entitled to be considered as persons with constitutional rights co-extensive with those of actual individuals would have been inconsistent with the understanding of the relationship between the government and the corporation as of 1868. Even after the Fourteenth Amendment was ratified, the constitutional protections granted to corporations in judicial decisions were limited to property rights closely related to a corporation's ability to conduct its business and preserve its assets. ${ }^{19}$

15 Trs. of Dartmouth Coll. v. Woodward, 17 U.S. (4 Wheat.) 518, 636 (1819) (Marshall, C.J.).

16 See, e.g., James Willard Hurst, The Legitimacy of the Business Corporation in the Law of the United States 162 (1970).

$17 I d$. at 69.

$18 I d$. at 56.

19 Bloch \& Lamoreaux, supra note 1, at 5 ("The courts have always exhibited a willingness to protect the constitutional rights of the natural persons who joined corporations, but the extent to which a corporate entity could claim Fourteenth-Amendment protections on behalf of its members depended on the nature of their stakes. In the case of business corporations, these stakes have historically been limited to property rights."); see also Margaret M. Blair \& Elizabeth Pollman, The Derivative Nature of Corporate Constitutional Rights, 56 WM. \& MARY L. Rev. 1673, 1686-96 (2015). 
Thus, we conclude that however Citizens United is rationalized, it cannot be defended solely or primarily as the product of a disciplined application of the originalist method of constitutional interpretation. Because Citizens United takes a view at odds both with the historical understanding of business corporations' legal subordination to the decisions made by elected legislators and the lengthy history of federal and state legislation restricting the involvement of for-profit corporations in the political process, it can be fairly described as more "original" than originalist.

\section{Originalism and Citizens United}

\section{A. Originalism}

There are many varieties of originalism, but most originalist theories can be divided into two broad categories: those that seek the original intention behind the Constitution or those that attempt to determine the original public understanding of the Constitution's meaning. ${ }^{20}$ Of these two, original intent is the older theory, and it was popularized by Raoul Berger and Robert Bork. ${ }^{21}$ Those who base their originalism on original intent try to discern the intention of "those actors whose decisions produced the constitutional language whose meaning is at issue: the framers at the Federal Convention or the members of the First Federal Congress (or subsequent congresses) who drafted later amendments." 22 This approach has been criticized ${ }^{23}$ and arguably would have been unrecognizable to the Founders themselves, who would have been more familiar with textualist than intentionalist methods of interpretation. ${ }^{24}$

The more current variant of originalism-which Randy Barnett has popularized as the "New Originalism"-looks to the original understanding of the framers' text. ${ }^{25}$ This form of originalism, to which Robert Bork later converted, can also be termed a theory of "intent," although it is an objective theory of intent. ${ }^{26}$ Relevant to our purposes now, Justice Scalia subscribes to this theory of original understanding, or original objective intent: he has stated that judges should look for "a sort of 'objectified' intent-the intent

20 Jack N. Rakove, Original Meanings: Politics and Ideas in the Making of the Constitution 7-9 (1997).

21 Raoul Berger, Government by Judiciary: The Transformation of the Fourteenth Amendment 402-27 (2d ed. 1997); Bork, supra note 11, at 13 ("The words [of the Fourteenth Amendment] are general but surely that would not permit us to escape the framers' intent if it were clear.").

22 Rakove, supra note 20, at 8.

23 See Paul Brest, The Misconceived Quest for the Original Understanding, 60 B.U. L. Rev. 204 (1980).

24 See, e.g., Rakove, supra note 20, at 339-65 (describing Madison's inconsistent use of originalism).

25 Randy E. Barnett, An Originalism for Nonoriginalists, 45 Loy. L. Rev. 611 (1999).

26 See Randy E. Barnett, The Gravitational Force of Originalism, 82 FordHam L. Rev. 411, 412-15 (2014); see also Robert H. Bork, The Tempting of America 144 (1990). 
that a reasonable person would gather from the text of the law." ${ }^{27}$ In other words, "the meaning which the subject is authorized to understand the legislature intended." 28

Justice Scalia is, in his own words, a "textualist-originalist."29 That means that Justice Scalia is committed to determining the meaning of a law from the text: when the text of a statute is clear, a judge may not go beyond it or twist its meaning to reach his or her desired result. ${ }^{30}$ If the text is unclear, a judge may employ canons of construction. Thus, for example, if a judge is faced with a statute containing a list of definite items and the phrase "other things" at the end, the "other things" are taken to be of the same kind as the definite items. ${ }^{31}$

Constitutional text presents a "distinctive problem" for Justice Scalia because the form of the text is different from that of a statute. 32 "In textual interpretation, context is everything, and the context of the Constitution tells us not to expect nit-picking detail, and to give words and phrases an expansive rather than narrow interpretation-though not an interpretation that the language will not bear." 33 To interpret the open-ended text of the Constitution, Justice Scalia looks to evidence of "how the text of the Constitution was originally understood." 34 When it comes to the Bill of Rights, Justice Scalia may look to the "writings . . . of . . . intelligent and informed people of the time." 35 Justice Scalia does not look to the Framers' intent, as Bork and Berger did, but to the meaning of the text as it was originally understood. ${ }^{36}$

This understanding of the text must, by definition, be rooted in the text itself. Therefore, when the text is unambiguous, there is no need for any historical inquiry. We do not need any interpretation of the Age Clause of Article II, Section 1, which provides that the President must be at least thirtyfive years old. ${ }^{37}$ Nor should we need any evidence to tell us how to interpret the Third Amendment's proscription against quartering soldiers in houses during peacetime without the owner's consent. ${ }^{38}$ We look to the text first; and if it is clear, that is the end of the matter. ${ }^{39}$

27 Antonin Scalia, A Matter of Interpretation 17 (1997).

$28 I d$. (emphasis omitted).

29 Id. at 132.

30 See, e.g., id. at 18-23 (discussing Church of the Holy Trinity v. United States, 143 U.S. 457 (1892)).

31 Id. at 26; see also ScAlia \& GARNER, supra note 14, at 199-213 (discussing ejusdem generis); infra note 106 (same).

32 SCALIA, supra note 27 , at 37.

$33 I d$.

$34 I d$. at 38 .

$35 I d$.

$36 I d$.

37 See Antonin Scalia, Originalism: The Lesser Evil, 57 U. Cin. L. Rev. 849, 862 (1989).

38 U.S. Const. art. II, § 1; see Scalia, supra note 27, at 134.

39 See Rutan v. Republican Party of Ill., 497 U.S. 62, 95 n.1 (1990) (Scalia, J., dissenting) ("I argue for the role of tradition in giving content only to ambiguous constitutional text; no tradition can supersede the Constitution."). 
If the text is unclear, though, we can then look to contemporaneous sources to determine the original understanding of the text. ${ }^{40}$ Justice Scalia's constitutional interpretation is thus analogous to the two-step process that courts employ when deciding whether to defer to an agency's interpretation of a statute under Chevron U.S.A, Inc. v. Natural Resources Defense Coun$\mathrm{cil}^{41}$ - a case with which he agrees. ${ }^{42}$ First, the court decides if the text is unclear. If the text is clear, that ends the inquiry, just as in Chevron. ${ }^{43}$ If the text is ambiguous, Justice Scalia (and a court applying Chevron) continues. A court reviewing an administrative decision will consider whether the agency's interpretation is reasonable; ${ }^{44}$ Justice Scalia will seek a reasonable original understanding of the text.

The qualifier "reasonable" is important. Justice Scalia admits that a rigid adherence to original understandings in this second step may be "medicine that seems too strong to swallow." $45 \mathrm{He}$ therefore dilutes it with various devices. One is an adherence to stare decisis. Scalia may go along with past decisions that he thinks are inconsistent with the original understanding, but calls this a "pragmatic exception" to originalism. ${ }^{46}$ Justice Scalia does not confine himself to sources from the time of the text's adoption, but will also rely on "traditions," however defined. ${ }^{47}$

One obvious challenge for an originalist judge is analyzing the evidence to determine the answer to a difficult historical question, when the more suited person for the task would be not a jurist but a professional historian, untroubled by the time pressure of publishing a judicial opinion. ${ }^{48}$ But, according to Justice Scalia,

While it may indeed be unrealistic to have substantial confidence that judges and lawyers will find the correct historical answer to such refined questions of original intent as the precise content of 'the executive Power' [in Article II, Section 1], for the vast majority of questions the answer is clear. ${ }^{49}$

We are not trying to praise or criticize Justice Scalia's method of originalism. We are simply attempting to set it out as clearly as possible so that we

40 Scalia \& Garner, supra note 14 , at 78-92.

41 Chevron U.S.A. Inc. v. Nat. Res. Def. Council, Inc., 467 U.S. 837, 842-43 (1984).

42 See, e.g., City of Arlington v. FCC, 133 S. Ct. 1863, 1872-73 (2013); United States v.

Mead Corp., 533 U.S. 218, 239 (2001) (Scalia, J., dissenting).

43 Chevron, 467 U.S. at 842-43.

44 Id. at 843-44.

45 Scalia, supra note 37 , at 861 .

46 ScAlia, supra note 27, at 140 (emphasis omitted).

47 See, e.g., Roper v. Simmons, 543 U.S. 551, 609 (2005) (Scalia, J., dissenting); Planned Parenthood of Se. Pa. v. Casey, 505 U.S. 833, 1000 (1992) (Scalia, J., concurring in the judgment in part and dissenting in part).

48 Scalia, supra note 37, at 860-61; see also McDonald v. City of Chicago, 561 U.S. 742, 803-04 (2010) (Scalia, J., concurring) ("Historical analysis can be difficult; it sometimes requires resolving threshold questions, and making nuanced judgments about which evidence to consult and how to interpret it. I will stipulate to that.").

49 Scalia, supra note 37 , at 863 . 
can judge the originalist concurrence in Citizens United against the methodology it purports to employ. ${ }^{50}$ We now look at the concurrence in detail.

\section{B. The Scalia-Stevens Debate About Whether the Result Can Be Defended as Originalism}

In its ruling, the Citizens United majority deviated from the doctrine of stare decisis by overturning its recent decision in McConnell v. FEC, in which McCain-Feingold's restrictions on corporate and labor political activities had been found constitutional. ${ }^{51}$ The McCain-Feingold Act made it unlawful for "any corporation ... or any labor organization [ ] to make a contribution or expenditure in connection with any [federal] election." 52 Contributions and expenditures were defined to include any payment for an "electioneering communication," 53 which included advertisements referring to a "clearly identified candidate for Federal office" within sixty days of a general election and thirty days of a primary. ${ }^{54}$ These restrictions did not, however, prevent corporations and unions from forming political action committees to help employees, stockholders, and members pool their funds in support of candidates. ${ }^{55}$ The Court upheld these restrictions as constitutional in McConnell. ${ }^{56}$

In Citizens United, the Court changed course and held that McCain-Feingold's restriction on expenditures by corporations and unions on electioneering communications was unconstitutional. ${ }^{57}$ Justice Scalia, joined by Justices Alito and Thomas, wrote a concurrence that advanced an originalist theory why corporations should be able to make unlimited corporate expenditures expressly advocating the election or defeat of political candidates. ${ }^{58}$

Justice Scalia wrote his concurrence to rebut Justice Stevens's own historical exposition, which argued that corporations had no right at the time of the framing of the Constitution to engage in political speech. ${ }^{59}$ Justice Stevens pointed out that, to the extent that it was possible to discern the intentions of the Framers of the Constitution and that these intentions were relevant to the case, they tended to undermine the majority's position. ${ }^{60}$ Justice Stevens observed that corporations were rare before the ratification of

50 Talented thinkers have criticized it, of course. See, e.g., Richard A. Posner, The Incoherence of Antonin Scalia, New Republic (Aug. 24, 2012), http://www.newrepublic.com/arti cle/magazine/books-and-arts/106441/scalia-garner-reading-the-law-textual-originalism; see also Richard A. Posner, Reflections on Judging 182 (2013).

51540 U.S. 93 (2003).

522 U.S.C. $\$ 441 \mathrm{~b}(\mathrm{a})(2006)$.

$53 I d . \$ 441 \mathrm{~b}(\mathrm{~b})(2)$.

54 Id. $\S 434(\mathrm{f})(3)(\mathrm{A})(\mathrm{i})$.

55 See id. $\S 441 \mathrm{~b}(\mathrm{~b})(2)$.

56540 U.S. at $189-94$.

57 Citizens United v. FEC, 558 U.S. 310, 365-66 (2010).

58 Id. at 385-93 (Scalia, J., concurring).

$59 I d$. at 425-32 (Stevens, J., concurring in part and dissenting in part).

$60 I d$. at $426-27$. 
the First Amendment in 1791, and those few that existed owed their existence to special legislative charters. ${ }^{61}$ These special charters enumerated the activities that the corporation could engage in. Moreover, a corporation could only obtain a charter if its activities would be "consistent with public welfare." 62

Thus, according to Justice Stevens, the framers "took it as a given that corporations could be comprehensively regulated in the service of the public welfare." ${ }^{63}$ And this dovetailed with the original understanding of the First Amendment: "Unlike our colleagues, they had little trouble distinguishing corporations from human beings, and when they constitutionalized the right to free speech in the First Amendment, it was the free speech of individual Americans that they had in mind." 64 Therefore, there was no conflict between a state's right to regulate its corporations and the speech rights guaranteed to Americans by the First Amendment.

Justice Scalia disputed this evidence. He argued that there was no basis to limit corporate political speech on the ground that corporations, at the time of the framing, were only permitted to engage in limited activities specifically authorized by their charters. ${ }^{65}$ Justice Scalia appeared to presume that corporations did have political speech rights in 1791, and asserted that there was "no evidence," "none whatever," that the protections of the First Amendment did not extend to corporations. ${ }^{66}$ He claimed that, at the time of the ratification of the Bill of Rights, no distinction was drawn between corporations and natural persons for the purposes of speech rights, and so corporations could not be excluded from the coverage of the First Amendment. Justice Scalia responded to Justice Stevens's contention that the First Amendment protected only the individual rights of Americans by noting that it was correct that the First Amendment was designed to protect the "rights of individual men and women-not, for example, of trees or polar bears. But the individual person's right to speak includes the right to speak in association with other individual persons." 67 Therefore, he wrote, if we interpret the First Amendment in accordance with its "original meaning," it cannot be construed to prevent corporations from being involved in the electoral process. ${ }^{68}$

For much of his concurrence, Justice Scalia argued that there was no evidence that the government had the right to regulate the speech of forprofit corporations. That is clearly a resort to step two of the originalist inquiry, as we have described it in Section I.A above. But Justice Scalia's con-

\section{$61 \quad I d$.}

$62 I d$. at 427 (quoting Ronald E. Seavoy, The Origins of the American Business CorPORATION, 1784-1855, at 5 (1982)).

$63 I d$. at 428.

64 Id

65 Id. at 385-93 (Scalia, J., concurring).

$66 \quad I d$. at 389.

67 Id. at 391-92.

68 Id. at 393. 
currence also argues repeatedly that the text is unambiguous-and so we should not begin a historical inquiry. Justice Scalia points out that the "constitutional text ... makes no distinction between types of speakers" 69 and that there is no "textual exception for speech by corporations."70 Rather, the First Amendment's text is "unqualified"71 and "[i] ts text offers no foothold for excluding any category of speaker."72 All that matters is that Congress may not regulate speech. ${ }^{73}$

This should be enough, one might think, to cut off the Chevron-style originalism inquiry at step one: if the constitutional text is clear and unambiguous, no additional analysis is required-or allowed. But this cannot be true. For a start, as Justice Scalia acknowledges, the Bill of Rights only protects "the rights of individual men and women-not, for example, of trees and polar bears."74 The First Amendment speaks to the abridgment of the "freedom of speech," and not to whether that freedom extended to artificial entities that at the time were rare and specifically chartered to serve specific purposes. A business corporation is not simply "individual men and women": it is a distinct entity that is legally separate from its stockholders, managers, and creditors. This is the whole point of corporate law after all, ${ }^{75}$ and one that Justice Scalia implicitly acknowledges in his concurrence. ${ }^{76}$ Justice Scalia has also candidly noted that for-profit corporations do not have the objective of expressing opinions by stating that " $[t]$ he Campbell Soup Company does not exist to promote a message."77 Therefore Justice Scalia must

69 Id. at 386.

70 Id. at 388

$71 \quad I d$. at 389.

72 Id. at 392-93.

$73 \mathrm{Id}$.

$74 \quad I d$. at 391-92.

75 See, e.g., Larry E. Ribstein, The Rise of the Uncorporation 73 (2010) ("The corporation has been regarded from its inception as a legal entity distinct from its owners.").

76 To contend that a corporation is the owner of its equity is to reject corporation law itself. Corporations have perpetual existence, are not owned by anyone (stockholders own shares with certain legal rights, not pieces of the corporation), and have a separate legal existence from the stockholders, managers, and creditors. See Robert Stephen M. BainBRIDGE, CORPORATE LAW 2 (2d ed. 2009) ("[T]he corporation is an entity wholly separate from the people who own it and work for it.”); Charles Clark, Corporate Law $§ 1.2 .3$, at 15-21 (1986); 12B William Meade Fletcher, Fletcher Cyclopedia of the Law of CorpoRATIONS $\$ 5709$ (rev. vol. 2015) ("[A] corporation is an entity distinct from its shareholders ...."). Justice Scalia concedes that "corporations [can] pursue only the objectives set forth in their charters," whereas, of course, individuals may pursue whatever legal goals they like. Citizens United, 558 U.S. at 386 (Scalia, J., concurring).

Below, we discuss further problems with Justice Scalia's view that corporations are merely a vehicle for the "individuals" that "associat[e]" to form them. See infra note 166 and accompanying text. Indeed, it is a stretch to say the modern corporation is an association of individuals, given that most corporate stock is held by institutional investors. See Edward B. Rock, Adapting to the New Shareholder-Centric Reality, 161 U. PA. L. Rev. 1907, 1922 (2013).

77 Wash. State Grange v. Wash. State Republican Party, 552 U.S. 442, 467 (2008) (Scalia, J., dissenting). 
resort to the second step of the originalist inquiry to determine whether it was understood at the time of the Founding that Congress could restrict corporations' speech rights.

Furthermore, it seems unreasonable to ascribe to Justice Scalia the view that speech in and of itself is all that matters, because under well-settled First Amendment doctrine, there are numerous exceptions to speech rights that depend on the type of speech ${ }^{78}$ and the identity of the speaker. ${ }^{79}$ Justice Scalia has authored opinions arguing that the government may restrict speech based on the identity of the speaker. ${ }^{80}$ By way of pertinent example, Scalia has been unwilling to accord the same speech rights to labor unions as he contends corporations possess. ${ }^{81}$ And Justice Scalia himself has admitted in his extrajudicial writing that applying the First Amendment to modern contexts, such as television, "is not entirely cut-and-dried but requires the exercise of judgment." 82 Therefore, we do not ascribe to Justice Scalia the view that the First Amendment is clear on its face as a textual matter as to the

78 See, e.g., Harper \& Row, Publishers, Inc. v. Nation Enters., 471 U.S. 539 (1985) (holding that speech of ideas belonging to others is unprotected); Miller v. California, 413 U.S. 15 (1973) (holding that obscene speech is unprotected); Chaplinsky v. New Hampshire, 315 U.S. 568 (1942) (holding that fighting words are unprotected).

79 Citizens United, 558 U.S. at 420 (Stevens, J., dissenting) (listing constitutional restraints that the government puts on the speech rights of students, prisoners, foreigners, and its own employees).

80 E.g., Bd. of Cty. Comm'rs v. Umbehr, 518 U.S. 668, 686-711 (1996) (Scalia, J., dissenting) (arguing that the government should be permitted to retaliate against a contractor on the basis of that contractor's political speech); Rutan v. Republican Party of Ill., 497 U.S. 62, 92-115 (1990) (Scalia, J., dissenting) (arguing that it should be constitutional for a government employer to reject an applicant on the basis of his or her political speech); David Schultz, Justice Antonin Scalia's First Amendment Jurisprudence: Free Speech, Press and Association Decisions, 9 J.L. \& PoL. 515, 519 (1993) (“[W] hile [his] participation in certain high profile decisions striking down flag burning or cross burning laws as unconstitutional have given him a reputation as a defender of free speech, press and association, he is not. In the forty-six identified cases involving these freedoms, he has voted against them thirtythree times.").

81 In Knox v. Service Employees International Union, Local 1000, 132 S. Ct. 2277 (2012), the Court ruled that labor unions were not permitted to require nonmembers to pay fees to fight a referendum. By parity of reasoning to Citizens United, labor unions should get to use treasury funds on the same basis as corporate boards. Strine \& Walter, supra note 1, at 365-67 (discussing the restrictions placed on union dues by Abood v. Detroit Bd. of Educ., 431 U.S. 209 (1977)). If the reasoning of Abood were applied to corporations, as it more than plausibly could, corporations could not use treasury funds for political purposes and could only use funds specifically raised from stockholders for those purposes, consistent with the design of McCain-Feingold.

82 SCAlia, supra note 27, at 45. Indeed, one thing that originalists of all stripes tend to agree on is that the First Amendment is resistant to historical inquiry. Bork, supra note 11, at 22; accord BALKIN, supra note 7, at 265 ("History gives us relatively little help in determining what principle or principles underlie the words 'freedom of speech."”). 
question of whether it accords any rights to corporations, much less whether those rights are identical to those it grants to humans. ${ }^{83}$

\section{An Analysis of Citizens United According to Justice Scalia's Originalism}

We now embark on our own, historical inquiry to determine who got the better of this debate. Before we do so, however, we must say a few more words about our method of originalism. We will hew to Justice Scalia's approach: we do not claim that the text of the First Amendment alone resolves this issue, and therefore we will look to historical practice. But we must consider the relevant time period for our inquiry. We will first look at the understanding of the First Amendment at the time that it was adopted by Congress. The debate between Justice Scalia and Justice Stevens focused on the meaning of the First Amendment in 1789-91; and there would not have been any reason for them to look at any other point in time, because they were debating the constitutionality of a federal law in Citizens United.

But the First Amendment, like most other provisions of the Bill of Rights, has since been incorporated against the states after the passage of the Fourteenth Amendment. ${ }^{84}$ And the reasoning in Citizens United has been extended to invalidate state restrictions on corporate political spending. ${ }^{85}$ Because the First Amendment was incorporated against the states via the Due Process Clause of the Fourteenth Amendment, it may be argued that the relevant time period for analyzing state restrictions on corporate political spending is not 1789-91, but 1866-68. As important, the Fourteenth Amendment could have been intended to broaden the category of legally recognized persons who could exercise rights granted in the Bill of Rights. That is, we also consider whether the Fourteenth Amendment was understood as putting corporations on the same footing as human beings in terms of possessing enforceable constitutional rights.

Thus, like some scholars, we analyze the relevant questions of publicly understood meaning at both relevant time periods. ${ }^{86}$ In Part IV, we discuss

83 Such a view would also be inconsistent with his nonjudicial writings. See, e.g., ScAliA, supra note 27, at 37-38 (observing that the First Amendment must be construed to protect handwritten letters, even though they are not speech or press). It would also be in tension with his judicial opinions on who has standing to sue to assert a right in federal court. See Gene R. Nichol, Jr., Justice Scalia, Standing, and Public Law Litigation, 42 Duke L.J. 1141 (1993) (discussing Justice Scalia's limited view of standing).

84 See Gitlow v. New York, 268 U.S. 652, 668 (1925).

85 See Am. Tradition P'ship v. Bullock, 132 S. Ct. 2490, 2491 (2012) (per curiam).

86 One author who has studied the original understanding of corporations' political speech rights has written that "[o]f course, for an originalist, delineating the proper scope of state restrictions on corporate speech would have to take into account the views of the generation that drafted and ratified the Fourteenth Amendment." Speir, supra note 1, at 179. Others agree. See David Bernstein, Incorporation, Originalism, and the Confrontation Clause, Volokh Conspiracy (July 6, 2009, 10:14 PM), http://volokh.com/posts/12469328 $56 . s h t m l$ ("When a right protected by the Bill of Rights is applied to the states via the 14th Amendment, it has to be the 1868 understanding of that right, not the 1791 understand- 
whether the First Amendment gave corporations the speech rights guaranteed to natural persons. Finding that the text of the Amendment does not answer this question, we examine the historical treatment of corporations before 1800 and find that there is no evidence that corporations were permitted to act on the political process without restriction. Rather, the evidence is that the sovereign that chartered a corporation could exercise tight control over it. In Part V, we discuss the development of the rights of corporations between 1800 and the enactment of the Fourteenth Amendment. We find that nothing in this period changed the existing conception of the corporation: the corporation had limited rights protecting its property, but no rights that could not be described as necessary or incidental to its existence. In Part VI, we discuss the Fourteenth Amendment and developments in corporate law after 1868. Again, we first look to the text of the Amendment, and find that there is nothing in the text that can be read as granting corporations the right of a natural person to speak generally, and more specifically the right to spend money in the political process. Having found the text to be silent, we examine legal developments in the fifty years following 1868. Although corporate law doctrines changed during this period, we find nothing that leads us to conclude that, as a historical matter, a corporation was considered as of the time of the enactment of the Fourteenth Amendment to be free to engage in political speech with treasury funds on the same basis as a human person; much less that the government could not restrict the means by which corporations could do so, along the lines that McCain-Feingold did.

Thus, no matter what period is used, an originalist interpretation of the First Amendment cannot justify the holding in Citizens United. In fact, the strong weight of the historical evidence would support the notion that government could impose restrictions on corporate political spending that it could not impose on human beings.

\section{The Understanding of Corporations as of the Adoption of the First Amendment}

\section{A. Corporations Are the Opposite of Lockean-Jeffersonian Human Beings}

Determining whether the public at the time of the Founding viewed corporations as having rights coextensive with individual citizens is not hard, because the historical record is clear that it would have been alien to any of

ing, that governs.”); see also Josh Blackman \& Ilya Shapiro, Keeping Pandora's Box Sealed: Privileges or Immunities, The Constitution in 2020, and Properly Extending the Right to Keep and Bear Arms to the States, 8 Geo. J.L. \& Pub. Pol'y 1, 51-54 (2010) (endorsing Bernstein's theory). Akhil Amar relies on the meaning of rights in 1868 in his work. E.g., AkHIL ReED Amar, America's Constitution: A Biography 322-27 (2005) (comparing the understanding of the Second Amendment in 1789 to 1866); see Sunstein, supra note 7 (Amar's work has some features of originalism).

Justice Scalia, by contrast, focuses on colonial and early state practices even when interpreting provisions of the Bill of Rights applied to the States. See, e.g., Crawford v. Washington, 541 U.S. 36, 42-50 (2004). We do not take sides in this debate. 
the Founders or their fellow Americans for anyone to assert that any corporation had any right to do anything that it was not specifically authorized to do by a specific act of the legislature. Just as it was self-evident that "all Men . . . [were] endowed by their Creator with certain unalienable Rights," such as "Life, Liberty, and the Pursuit of Happiness," it was self-evident that all corporations were endowed by their creator-the chartering authority, such as the state legislature-only with those rights that their creators saw fit to give. ${ }^{87}$ As we discuss, corporations existed only if a legislature created them and they were empowered to do only that which the legislature said they could do.

In other words, it was widely understood that human beings and corporations had precisely the opposite relationship to society in terms of rights. ${ }^{88}$ Human beings were born with inalienable rights that government could not take away; corporations had only such rights as the government chose to give to them. Even though the law identified a corporation with its flesh-andblood owners for some limited purposes, the rights given to for-profit commercial corporations did not include the right to speak as a flesh-and-blood citizen.

\section{B. Corporations in England and Colonial North America}

The first corporations chartered in Europe in the Middle Ages were not business corporations. Rather, they were religious, municipal, and benevolent corporations. ${ }^{89}$ Typical among the earliest corporations is the almshouse and school in the Sutton's Hospital case, which was decided in England in 1613 and was of major significance in the later law of corporations. ${ }^{90}$ In June 1611, James I granted letters patent to Thomas Sutton permitting him to found a hospital in London. ${ }^{91}$ Sutton died shortly afterward and left property to the hospital in his will. ${ }^{92}$ But Sutton had not founded the hospital by the time of his death, so his human heirs challenged the bequest: How could an entity that did not exist inherit property? ${ }^{93}$ To this, Edward Coke, then Chief Justice of the Common Pleas, replied that a corporation named in a charter could receive property even before it began operating, because, by definition, a corporation was a legal construct:

And it is great reason that an hospital, \&c. in expectancy or intendment, or nomination, should be sufficient to support the name of an incorporation when the corporation itself is only in abstracto, and rests only in intendment

87 The Declaration of Independence pmbl. (U.S. 1776) (emphasis added).

88 See Morton J. Horwitz, Santa Clara Revisited: The Development of Corporate Theory, 88 W. VA. L. Rev. 173, 184 (1985) ("The corporation ... stood in clear contradiction to a legal culture dominated by Lockean ideas of pre-social natural rights.").

89 Hurst, supra note 16, at 2-3.

90 The Case of Sutton's Hosp., (1613) 77 Eng. Rep. 937 (K.B.); 10 Co. Rep. 1a.

91 Id. at $961 ; 10$ Co. Rep. at 23a-b.

92 Id.

93 Id. at 961-62; 10 Co. Rep. at 23b-24a. 
and consideration of the law; for a corporation aggregate of many is invisible, immortal, and rests only in intendment and consideration of the law . . . ${ }^{94}$

This holding is relevant to our present inquiry. Because corporations were legal constructs, Coke said, they did not possess human capabilities:

They cannot commit treason, nor be . . . outlawed, nor excommunicate, for they have no souls, neither can they appear in person, but by attorney. A corporation aggregate of many cannot do fealty, for an invisible body can neither be in person, nor swear, it is not subject to imbecilities, death of the natural body, and divers other cases. ${ }^{95}$

Corporations did, however, possess certain other attributes, "tacit[ly] annexed" to them, without which they would be of little utility. ${ }^{96}$ Because these attributes were "tacit[]," they did not need to be spelled out in the charter. Thus, "corporation is sufficient without the words to implead and to be impleaded, \&c. and therefore divers clauses subsequent in the charters are not of necessity, but only declaratory, and might well have been left out." 97 It was not necessary that the charter recite that the corporation could receive and sell property; this was "incident" to the corporation's existence. ${ }^{98}$ As we shall see, Coke's conception of the corporation-an entity with certain legal rights that would enable it to perform its function, but with no human characteristics such as the ability to commit treason-held sway in the eighteenth and nineteenth centuries.

Business corporations first appeared in England in the late sixteenth century in the form of foreign trading ventures. ${ }^{99}$ But they were not common in England, and were still less common in the American colonies. ${ }^{100}$ All

94 Id. at 973; 10 Co. Rep. at 32b (emphasis added).

95 Id. (citations omitted).

96 Id. at $970 ; 10$ Co. Rep. at $30 \mathrm{~b}$.

97 Id. (emphasis added).

$98 I d$. Coke suggested that the charter might ideally spell out the corporation's legal attributes "to oust doubts and questions which might arise," but little was formally required in the charter. Id. The requirements were: (1) "[l] awful authority of incorporation," such as Parliament or the King; (2) the "persons to be incorporated"; (3) a name; and (4) a place. Id. at 968-69; 10 Co. Rep. at 29b. The charter should include "every thing which is of the essence of the incorporation," but certain attributes of the corporate form, such as "to implead and to be impleaded, to grant and purchase, \&c. are incidents to a body incorporate." Id.

99 Hurst, supra note 16, at 4; see, e.g., Liam Séamus O’Melinn, Neither Contract nor Concession: The Public Personality of the Corporation, 74 GEo. Wash. L. REv. 201, 217-18 (2006) (observing that before 1811, there were no general incorporation statutes pertaining to business organizations, but only for churches, charitable societies, literary societies, and libraries).

100 Hurst, supra note 16, at 7 ("[N]o evidence of significant demand for corporate charters for local enterprise until about 1780 . ..."). Samuel Williston identifies only six "joint-stock business corporations chartered in America before 1787." Samuel Williston, History of the Law of Business Corporations Before 1800, 2 HARv. L. REv. 149, 166 (1888). Only one of those on Williston's list predates 1776, the Philadelphia Contributionship for the Insuring of Houses from Loss by Fire, which was chartered by Pennsylvania in 1768. Id. at 165. Simeon Baldwin identifies six business corporations chartered during the colonial 
these corporations were created through special charters. In the colonies, the power to issue charters was split between the governor, the colonial legislature, and the proprietor in proprietary colonies. ${ }^{101}$

William Blackstone, whose influence on Founding-era lawmakers and jurists has been well documented, devoted a section of his Commentaries to corporations. ${ }^{102}$ In Blackstone's view, corporations were created "for the advantage of the public": their chief benefit was that they had perpetual life. ${ }^{103}$ The king's consent was required for any act of incorporation: the king could create corporations himself or, if Parliament exercised its authority to create a corporation, the king could veto Parliament's act. ${ }^{104}$

Like Coke, Blackstone noted that a corporation held some rights, in addition to those expressly set out in its charter, as "incidents . . . tacitly annexed of course." 105 These rights included "[t]o sue or be sued, implead or be impleaded, grant or receive, by [its] corporate name."106 But, also like Coke, Blackstone noted that corporations did not have the full rights of natural persons: they could not commit treason, or act as a trustee, or appear in

era: the New York Company "for Settleing a Fishery in these parts," of 1675; the Free Society of Traders, chartered by Pennsylvania in 1682; the New London Society United for Trade and Commerce (Connecticut 1732); the Union Wharf Company (Connecticut 1760); the Philadelphia Contributionship, cited by Williston; and the Long Wharf in Boston, chartered in 1772. Simeon E. Baldwin, American Business Corporations Before 1789, 8 Ам. Hist. Rev. 449, 450 (1903). Lawrence Friedman, citing Joseph Davis, identifies seven colonial business corporations. Lawrence M. Friedman, A History of American Law 130 (3d ed. 2005) (citing 2 Joseph S. Davis, Essays in the Earlier History of American CorPORATIONS 24 (1917)). But however early business corporations are defined, it is clear that there were very few of them. See, e.g., McKim v. Odom, 3 Bland. 307, 418 (Md. Ch. 1828) ("It is remarkable, that there is no instance of the creation of any body politic of this description under the Provincial government [viz., the Province of Maryland].”). The dominant early form of business organization was the partnership. Friedman, supra, at 130 .

101 Hurst, supra note 16, at 14, 115.

1021 William Blackstone, Commentaries *455-73; see Albert W. Alschuler, Rediscovering Blackstone, 145 U. PA. L. Rev. 1 (1996).

1031 Blackstone, supra note 102 , at $* 455$.

$104 I d$. at $* 461-62$.

$105 I d$. at $* 463$.

106 Id. This sentence ends "and do all other acts as natural persons may." Given the differences that Blackstone acknowledged between corporations and natural persons, it is obvious that Blackstone did not mean that corporations had all the rights of natural persons. Rather, by his phrase "sue or be sued, implead or be impleaded, grant or receive, by [its] corporate name, and do all other acts as natural persons may," Blackstone expects us to interpret his words with the help of the ejusdem generis canon: "[w] here general words follow an enumeration of two or more things, they apply only to persons or things of the same general kind or class specifically mentioned." SCALIA \& GARNER, supra note 14, at 199. Thus, Justice Scalia would, we assume, interpret the phrase "all other acts as natural persons may" to include only such other acts similar to those previously listed-for example, to lease property. It would be inconsistent with canons of construction to interpret this phrase as including, for example, the right to give money to a natural person's parliamentary campaign. 
court. ${ }^{107}$ Blackstone spoke little about commercial corporations as opposed to municipal or religious corporations. But to the extent that he discussed business corporations, he made clear that they had fewer rights than other corporations. According to Blackstone, each corporation had "inseparably incident" to itself the power to make its own bylaws, "[b]ut no trading company is, with us, allowed to make bye-laws, which may affect the king's prerogative, or the common profit of the people, unless they be approved by the chancellor, treasurer, and chief justices, or the judges of assise in their circuits." 108 Thus, the rights of business corporations were even more circumscribed than those of other corporations.

\section{Corporations in North America at the Time of the Founding}

After the American Revolution, the power to create corporations was vested in state legislatures. ${ }^{109}$ Although the corporate form grew in popularity after independence, corporations remained creatures of special statutes. ${ }^{110}$ There were no general incorporation acts at this time, like the acts under which corporations are chartered today. ${ }^{11}$ These acts only became common in the two decades before the Civil War. ${ }^{112}$ Instead, at the time of the Founding, it was necessary to obtain a charter from the legislature for a particular entity. ${ }^{113}$

The lack of general incorporation statutes for businesses reflects a general mistrust in the Founding era of the corporate form, and business corporations in particular. Thomas Jefferson hoped that the new country could "crush in [its] birth the aristocracy of our monied corporations which dare already to challenge our government to a trial of strength and bid defiance to the laws of our country."114 James Madison wrote that "[i]ncorporated Companies with proper limitations and guards, may in particular cases, be useful; but they are at best a necessary evil only." 115 James Wilson warned: "It must be admitted . . . that, in too many instances, those bodies politick [i.e., corporations] have, in their progress, counteracted the design of their original formation. ... [T] hey should be erected with caution, and inspected with

1071 Blackstone, supra note 102 , at $* 464$.

$108 I d$. From an originalist perspective, this restriction has a modern-day relevance: if, for example, a corporation passed a bylaw empowering an officer to give money to support a candidate in a parliamentary election, this bylaw could be invalidated on the ground that it was not in the public interest.

109 Hurst, supra note 16, at 14.

110 Three-hundred and seventeen business corporations were chartered between 1780 and 1801, compared to only a handful before independence. Id. at 14 .

111 O'Melinn, supra note 99, at 216.

112 See Hamill, supra note 13, at 97-102.

113 O'Melinn, supra note 99, at 216.

114 Thomas Jefferson, Letter to George Logan (Nov. 12, 1816), in 12 The Works of Thomas Jefferson 42, 44 (Paul Leicester Ford ed., 1905), cited in Citizens United v. FEC, 558 U.S. 310, 427 n.54 (2010) (Stevens, J., dissenting).

115 James Madison, Letter to James K. Paulding (Mar. 10, 1827), in 9 The Writings of James Madison 281, 281 (Gaillard Hunt ed., 1910). 
care."116 At the Constitutional Convention, the Framers rejected Madison's proposal that Congress should be permitted to issue charters to corporations "in cases where the Public good may require them, and the authority of a single State may be incompetent." 117 It was generally assumed that the power to charter these potentially dangerous entities was to be limited to the states-whereby the corporations would be weaker, and easier to regulate. ${ }^{118}$

116 James Wilson, Of Corporations, in 2 Collected Works of James Wilson 1035, 1035 (Kermit L. Hall \& Mark David Hall eds., 2007).

117 Hamill, supra note 13, at 90 (quoting The Records of the Federal Convention of 1787, at 325 (Max Farrand ed., 1937)).

118 Hamill, supra note 13, at 89. States retained complete control over corporations, because a state retained power over all corporations chartered by itself as well as corporations chartered by other states operating within its jurisdiction. See, e.g., Bank of Augusta v. Earle, 38 U.S. 519, 590 (1839) (a state had the power to pass legislation preventing a foreign bank from making contracts in its territory); see also Hooper v. California, 155 U.S. 648,652 (1895) (" $[\mathrm{T}]$ he right of a foreign corporation to engage in business within a State other than that of its creation, depends solely upon the will of such other State, has been long settled ...."); George W. Wickersham, State Control of Foreign Corporations, 19 YALE L.J. 1, 4-5 (1909) (discussing states' near-plenary power to regulate foreign corporations).

Mistrust of corporations survived well beyond the lifetime of the Founding Fathers. In 1832, Andrew Jackson vetoed the renewal of the charter of the Second Bank of the United States on the ground that it was an unconstitutional monopoly serving the interests of the rich, and urged that "we ... take a stand against all new grants of monopolies and exclusive privileges." Andrew Jackson, Veto Message (July 10, 1832), reprinted in 2 Messages AND Papers of the Presidents 1817-1833, at 576 (regarding the Bank of the United States). In his Farewell Address in 1837, he again warned against the social harm that could be caused by corporate wealth:

The agricultural, the mechanical, and the laboring classes have little or no share in the direction of the great moneyed corporations, and from their habits and the nature of their pursuits they are incapable of forming extensive combinations to act together with united force.... [W] ith overwhelming numbers and wealth on their side they are in constant danger of losing their fair influence in the Government, and with difficulty maintain their just rights against the incessant efforts daily made to encroach upon them. The mischief springs from the power which the moneyed interest derives . . f from the multitude of corporations with exclusive privileges which they have succeeded in obtaining in the different States, and which are employed altogether for their benefit; and unless you become more watchful in your States and check this spirit of monopoly and thirst for exclusive privileges you will in the end find that the most important powers of Government have been given or bartered away, and the control over your dearest interests has passed into the hands of these corporations.

Andrew Jackson, Farewell Address (Mar. 4, 1837), reprinted in 3 Messages and Papers of THE Presidents, 1833-1841, at 292, 305-06. . That same year, Martin Van Buren, the new President, declared in his first Address to Congress that he was "more than ever convinced of the dangers to which the free and unbiased exercise of political opinion-the only sure foundation and safeguard of republican government-would be exposed by any further increase of the already overgrown influence of corporate authorities." Martin Van Buren, First Annual Message to Congress (Dec. 5, 1837), http://millercenter.org/president/van buren/speeches/speech-3589. 
And state politicians also worried about the power of corporations. The Pennsylvania Council of Censors wrote in 1784 that corporations were "against the spirit and the policy of democracy" because they were capable of "holding common estates of large value, and exercising the power of making bye-laws." 119 The New York Council of Revision two years later held that corporations were "destructive of that principle of equal liberty which should subsist in every community." "20 James Sullivan, attorney general of Massachusetts, wrote in 1802 that " $[\mathrm{t}]$ he creation of a great variety of corporate interests ... must have a direct tendency to weaken the power of government."121 These concerns, to some extent, reflected those of the most prominent economist of the period, Adam Smith, who was hostile to corporations because they tended toward monopoly power. ${ }^{122}$ In Smith's view, the only corporations that could be safely chartered were those that required a privileged relationship with the chartering entity: domestic public service enterprises such as canals and schools, and insurance companies and banks. ${ }^{123}$

But to the extent that business corporations were seen as providing a public service, they were chartered to operate with the protection of limited liability. Their numbers at the time of the revolution were few. By 1787, less than a dozen business corporations had been chartered in the colonies. ${ }^{124}$ But the corporate form grew in popularity as the new country required infrastructure that could only be completed through the investment of capital: turnpikes, bridges, canals, and plank roads. ${ }^{125}$ These infrastructure developments were seen as beneficial and thus states acted to charter corporations to complete them. ${ }^{126}$ Insurance companies were also chartered because they too were seen as performing a public service. ${ }^{127}$ Banks were also seen as fulfilling a pressing public need and were granted special charters. ${ }^{128}$ The last category of business association to be chartered in this period was manufacturing companies. Like all of the previous categories, these were only chartered to the extent that they were deemed useful to society. Indeed, the "pioneering" Society for Establishing Useful Manufactures, which was incor-

119 Extract from the Minutes of the Council of Censors, PA. PACKeT (Phila.), Sept. 7, 1784, at 2, quoted in Speir, supra note 1, at 127-28.

120 Alfred Billings Street, The Council of Revision of the State of New York 261-64 (Albany, William Gould 1859), quoted in Speir, supra note 1, at 128.

121 FRIEDMAN, supra note 100, at 134.

1221 Adam Smith, The Wealth of Nations 116-17 (P.F. Collier \& Son 1909) (1776).

1233 Adam Smith, The Wealth of Nations 86-171 (P.F. Collier \& Son 1909) (1776); see also Ronald E. Seavoy, The Public Service Origins of the American Business Corporation, 52 Bus. Hist. Rev. 30, 32 (1978) (endorsing Adam Smith's view).

124 See supra note 100.

125 Seavoy, supra note 123 , at 45.

126 Henry Hansmann \& Mariana Pargendler, The Evolution of Shareholder Voting Rights: Separation of Ownership and Consumption, 123 YALE L.J. 948, 959 (2014).

127 Seavoy, supra note 123 , at 48.

$128 I d$. at 49. 
porated in New Jersey in 1791, advertised its public service function in its name. ${ }^{129}$

The rights and powers of the few corporations that existed were limited by statute. In other words, corporations could do only what their legislatively granted charters empowered them specifically to do, acts incidental to those specific powers, and nothing else. ${ }^{130}$ For example, New York in 1790 chartered the New York Manufacturing Society to "establish[] manufactories, and furnish[] employment for the honest industrious poor."131 The directors had power to pass bylaws and regulations that were "needful and proper" to the management of the corporation. ${ }^{132}$ But the special charter was silent as to participation in the political process, or as to speech rights more generally. Similarly, there were ten other corporations that were specially chartered in the United States in 1790 and 1791. ${ }^{133}$ But nothing in the charters of any of these corporations indicates they were permitted to involve themselves in the electoral process, even though the charters set out the acts that the corporations might undertake in extreme detail. ${ }^{134}$ Indeed, accord-

129 Hansmann \& Pargendler, supra note 126, at 986.

130 See, e.g., Head \& Amory v. Providence Ins. Co., 6 U.S. (2 Cranch) 127, 167 (1804) ("[A corporation] may correctly be said to be precisely what the incorporating act has made it, to derive all its powers from that act, and to be capable of exerting its faculties only in the manner which that act authorises.") (Marshall, C.J.) (emphasis added).

131 An Act To Incorporate the Stockholders of the New-York Manufacturing Society pmbl. (Mar. 16, 1790), reprinted in 2 Thomas Greenleaf, Laws of the State of New-York 309 (1792).

$132 I d . \$ 4$.

133 See Richard E. Sylla \& Robert E. Wright, U.S. Corporate Development 1801-1860 (NSF Grant no. 0751577) (on file with authors).

134 For example, the Maryland legislature enacted in 1791 "[a]n Act to establish a bank in Baltimore-town," which specified the day of the week on which a committee of directors would inspect the bank's books and the procedure whereby the bank's president would recover on delinquent loans. $1790 \mathrm{Md}$. Laws ch. V, $\S \S \mathrm{VI}, \mathrm{X}, \mathrm{XIII}$. The charter of the Bank of New York forbade the bank to hold any more real estate than was "requisite for its immediate accommodation, in relation to the convenient transacting of its business," and also provided that the bank could not "directly or indirectly, deal or trade, in buying or selling, any goods, wares, merchandize or commodities whatsoever, or in buying or selling any stock.” 1791 N.Y. Laws 237, 240. The charter for the Providence Bank, which was granted in 1791, provided for a minimum bond that cashiers and clerks must post. 1791 R.I. Pub. Laws 11, 1315. Nothing in these precise charters explicitly granted the banks power to contribute money to candidates for elected office or otherwise involve themselves in the political process, and the narrow restraints placed on the banks suggests that the banks would not have been seen to have this power.

The charters of canal companies were as precise as those of banks. For example, the Fayetteville Canal Company was incorporated in North Carolina in 1790. The company was authorized to "Make Cross Creek Navigable." The charter specified that the company might build dams and locks and to "clear [the creek] from trees, logs and other such things by which the said navigation might be obstructed.” 1790 N.C. Sess. Laws 98, 98. The Pennsylvania legislature chartered the Susquehanna and Schuylkill Navigation Company in a thirteen-page special act of 1791, setting out in detail how the company might obtain the land for the canal, construct it, and what rate of return it was to provide to its 
ing to one prominent nineteenth century treatise that we discuss, everything that was not "incidental" to the corporation's life was "illegal unless expressly authorized by the charter." 135

The first Anglo-American treatise devoted to corporation law, Stewart Kyd's Treatise on the Law of Corporations, was published in London in 1793, closer in time to the Founding than Blackstone and Coke. Kyd's treatise was used by lawyers on both sides of the Atlantic. ${ }^{136}$ And Kyd, like Coke and Blackstone before him, made clear that a corporation is a legal creation entirely under the control of the authority that created it:

A corporation ... is a collection of many individuals, united into one body, under a special denomination, having perpetual succession under an artificial form, and vested, by the policy of the law, with the capacity of acting, in several respects, as an individual, particularly of taking and granting property, of contracting obligations, and of suing and being sued, of enjoying privileges and immunities in common, and of exercising a variety of political rights, more or less extensive, according to the design of its institu-

shareholders. $1790 \mathrm{~Pa}$. Laws 150. The charter of incorporation of the New-Meadow Canal in Massachusetts was extremely brief-only five paragraphs-but it still regulated precisely the tolls that the canal could charge and the process for awarding damages to those whose land the canal crossed. 1791 Mass. Acts 110. As in the case of banks, nothing grants the canal companies power to spend money in support of candidates for elected office.

Some special charters were exercises of the state's police powers. In 1791, Maryland enacted a statute establishing the Maryland Fire Insurance Company, which banned private persons from holding more than thirty pounds of gunpowder in their homes. 1791 Md. Laws ch. 69, § XVII. All gunpowder in excess of this amount had to be turned over to the company, which would hold it in a magazine, and rates fixed in its charter. Id. ch. 69, $\S \S$ XVIII, XXV. But despite the company's public service function and monopoly powers, nothing in the charter explicitly or implicitly permitted it to become involved in politics. The broadest and most elaborate charter about the time of the Founding was that of the New Jersey Society for Establishing Useful Manufactures. This covered technical matters of corporate governance that remain of interest today (for example, whether directors could repeal a bylaw enacted by the stockholders, $c f$. Bebchuk v. CA, Inc., 902 A.2d 737, 743 \& n.37 (Del. Ch. 2006)), but also granted the Society remarkable powers, such as the ability to seize land through eminent domain to build canals and even incorporate a town, Paterson. 1791 N.J. Laws 720, 730. And, unusually, the charter provided that its provisions should be construed in the "most favorable Manner for the said respective Corporations," and that the Society could not forfeit its privileges through nonuser. Id. at 746. But even though the Society had broad powers for its time, its operations were closely regulated: the Society was not permitted to "deal, nor trade, except in such Articles as itself [should] manufacture" and the charter regulated even the kind of paint to be used to mark the tonnage of the vessels using the canals. $I d$. at 731, 739. In all of these detailed Foundingera charters, no text suggests that corporations were permitted to involve themselves in the political process by, for example, spending money on electoral campaigns.

135 Herbert Hovenkamp, The Classical Corporation in American Legal Thought, 76 GEO. L.J. 1593, 1663 (1988) (citing J. Angell \& S. Ames, A Treatise on the Law of Private Corporations Aggregate ch. 6 (Bos., Hilliard, Gray, Little \& Watkins 1832)).

1361 Stewart Kyd, A Treatise on the Law of Corporations (London, J. Butterworth 1793). For example, Kyd's treatise was cited by the petitioners in Bank of United States $v$. Deveaux, 9 U.S. (5 Cranch) 61, 64, 66 (1809). 
tion, or the powers conferred upon it, either at the time of its creation, or at any subsequent period of its existence. ${ }^{137}$

Restrictions on corporations were so tight that "when corporations are erected by act of parliament, for some particular purpose, it is frequently thought prudent to prohibit them, by an express clause, from purchasing lands beyond a certain annual value." ${ }^{38}$ Such a prohibition even applied to the East India Company, the most powerful business corporation in the world at the time. ${ }^{139}$

The restraints on corporations in their charters mattered, because at this time, the doctrines of ultra vires and quo warranto applied to corporations with full force. Under ultra vires, in the United States and England, all acts that were not authorized by a company's charter were null and void. ${ }^{140}$ Stockholders had the right to challenge ultra vires acts. ${ }^{141}$ An action under quo warranto, on the other hand, could only be brought by the sovereign, but it could lead to the dissolution of the corporation. ${ }^{142}$ "Quo warranto actions against corporations for nonuser-refusal to undertake the investment and business for which the corporation was designed-were common in the first half of the nineteenth century." 143 Thus, states retained full control over the corporations they chartered.

\section{Corporations and the First Amendment}

The First Amendment provides that "Congress shall make no law . . . abridging the freedom of speech."144 For reasons we have discussed, we do

\footnotetext{
137 KyD, supra note 136, at 13 (original emphasis omitted; new emphasis added).

138 Id. at 104.

139 Id

140 Albert J. Harno, Privileges and Powers of a Corporation and the Doctrine of Ultra Vires, 35 YALE L.J. 13, 22 (1925).

141 Hovenkamp, supra note 135, at 1662-63.

$142 I d$. at 1659.

$143 I d$. at 1660 (emphasis added). In America, an action by the sovereign to strip the corporation of its charter for nonuser could also be maintained under scire facias. For example, in Washington E Baltimore Turnpike Co. v. Maryland, 70 U.S. (3 Wall.) 210 (1865), the United States Supreme Court upheld the action of the State of Maryland in removing the charter of a company operating a turnpike between Washington and Baltimore under scire facias where the company had not kept the roads in repair, but still had demanded tolls. It was no defense to the scire facias action that the state had granted a charter to a railroad company along the same route, and that the turnpike company could no longer afford to maintain the road, because the turnpike company had not bargained for a monopoly in its charter. The Court held:
}

It might have been very proper for the State, when chartering the railroad, to have provided for compensation for the prospective loss to the turnpike company, as has frequently been done in other States, under similar circumstances; but this was a question resting entirely with the legislature of the State, and their action is conclusive on the subject.

Id. at 213 .

144 U.S. Const. amend. I. 
not ascribe to Justice Scalia the view that this language is clear on its face. ${ }^{145}$ Nor do we consider that the text clearly includes corporations within the scope of the constitutional guarantee. ${ }^{146}$ Therefore, we have summarized the evidence relating to the speech rights of business corporations at the time of the Founding, and found that business corporations had no such rights unless the legislature chose to grant them.

Justice Scalia's contrary contention is premised on an assumption that the Framers' failure to state explicitly that corporations did not have equal rights with human citizens reflected their tacit belief that corporations had whatever rights human citizens were granted by the Constitution. But as we have shown, that premise is unoriginalist and backward, because it takes interpretive license from a silence that is entirely understandable in light of the then-universally accepted understanding that corporations were creatures of government that had only such rights as were specifically granted to them. ${ }^{147}$ A corporation was the opposite of a Lockean-Jeffersonian human being with inalienable rights: corporations possessed no rights except those that were granted to them by the government. ${ }^{148}$ It would be more faithful to originalism to recognize that silence in terms of whether corporations were granted rights weighs against the conclusion that they had those rights.

Justice Scalia is also poorly positioned to chide Justice Stevens for not producing any evidence that corporations could participate in the electoral process at the time of the Founding. ${ }^{149}$ Given the heavy restrictions on corporate powers two hundred years ago, the burden should be on Justice Scalia to demonstrate that corporations had remarkable powers that even now many of us find strange and novel. All the evidence indicates that a state could restrict a corporation from speaking if it deemed that such speech was not in the public interest. And it also appears that the managers and stockholders of early corporations accepted that they were restricted from speaking in elections, for we have found no evidence that business corporations attempted to engage in political speech about the time of the Founding. No charter as of the Founding era exists of which we are aware that empowered a corporation to act on the political process by spending money to influence it. ${ }^{150}$

145 See supra Section II.B.

146 See, e.g., O’Kelley, supra note 9, at 1352.

147 Hovenkamp, supra note 135, at 1663.

148 John Locke, Two Treatises on Government, 195 (Peter Laslett ed., Cambridge Univ. Press 1988) (1689) ("To understand political power right, and derive it from its original, we must consider, what state all men are naturally in, and that is, a state of perfect freedom to order their actions, and dispose of their possessions and persons, as they think fit, within the bounds of the law of nature, without asking leave, or depending upon the will of any other man.”).

149 See Citizens United v. FEC, 558 U.S. 310, 386 (2010) (Scalia, J., concurring).

150 See supra note 134 (collecting early charters). Professor Hurst summarized the fundamental attributes of early American corporations as the rights "to sue and be sued, to hold and transfer title to real or personal property, [and] to act with legal effect under a 
This discussion is enough to establish that Justice Scalia's view of corporate speech rights at the time of the Founding is without strong historical foundation. Because his concurrence rested solely on Founding-era history, we could conclude here. But because we wish to show that, under any approach to originalism, it is not possible to ground the outcome in Citizens United on originalist reasoning alone, we now discuss whether corporations would have been deemed to have speech rights after 1868, because of the ratification of the Fourteenth Amendment.

\section{Corporations in the Antebellum Period}

We now trace the development of corporations' rights from 1800 to the Civil War. Our intent here is to determine whether anything about the public conception of a corporation had changed by the time the Fourteenth Amendment was ratified in 1868 . The short answer is no.

\section{A. Asserting a Constitutional Right: Individuals and Corporations}

We now turn to the question of who or what possessed a right guaranteed under the Constitution. In his originalist concurrence to Citizens United, Justice Scalia acknowledges that this is a relevant issue. ${ }^{151}$ An analysis of the evidence demonstrates that it was not the public understanding that humans could form a corporation that would have the same rights as the humans who created it. In fact, the prevailing public understanding was quite to the contrary.

An early Chief Justice Marshall decision, Bank of United States v. Deveaux, decided in 1809 , is relevant to our inquiry. ${ }^{152}$ Deveaux was the first in a trilogy of important cases involving unsuccessful state attempts to tax the Bank of the United States. ${ }^{153}$ In Deveaux, the board of the First National Bank sued two Georgia state officials who had used \$2,000 from the Savannah branch of the Bank to pay a Georgia state tax. ${ }^{154}$ The board sued first in the Circuit Court for the District of Georgia, and the defendants filed a plea in abatement on the ground that the court had no jurisdiction over the Bank. ${ }^{155}$ The district court, composed of Justice Johnson riding circuit and District Judge Stephens, sustained the plea in abatement for lack of diversity jurisdiction, albeit with reluctance. ${ }^{156}$ First, the court rejected the suggestion that the board members could sue in their individual capacities, because, if

common seal," as well as certain special privileges granted in specific cases (such as the right to operate turnpikes, canals, etc.). Hurst, supra note 16, at 19-20.

151 Citizens United, 558 U.S. at 391-92.

1529 U.S. (5 Cranch) 61 (1809).

153 The others were McCulloch v. Maryland, 17 U.S. (4 Wheat.) 316 (1819), and Osborn v. Bank of the United States, 22 U.S. (9 Wheat.) 738 (1824).

154 Deveaux, 9 U.S. (5 Cranch) at 62-63.

155 Bank of U.S. v. Deveaux, 2 F. Cas. 692, No. 916 (C.C.D. Ga. 1808) (per curiam), rev'd, 9 U.S. (5 Cranch) 61 (1809).

$156 I d$. at 693. 
so, "they must have sued by their baptismal names."157 But the court also rejected the alternative, which was that the Bank could sue as a corporation. The rights of individuals did not "pass through" to corporations, as Justice Scalia argues in his concurrence in Citizens United:

$[\mathrm{T}]$ he individual is so totally sunk in their corporate state of existence, that though it were true in fact, that the president, directors and company were all citizens of the state of Pennsylvania, still they could not communicate their right of suing in this court to the corporate body of which they are members. ${ }^{158}$

The Supreme Court reversed-but only to the barest extent possible to avoid the "embarrassment" 159 that would be caused if the Bank were not able to protect its interests by suing in federal court. ${ }^{160}$ First, Chief Justice Marshall reaffirmed that "[A] corporation . . . is certainly not a citizen." ${ }^{61}$ The Court thus accepted the district court's conclusion on this point. But the Supreme Court rejected the district court's view that a corporation could never sue in the federal courts. Rather, a court would, "for legitimate purposes" and "when the general spirit and purpose of the law requires it," consider a corporation as a "company of individuals." 162

Deveaux severely restricted the ability of corporations to sue in federal court. Indeed, it was acknowledged to be a "pure fiction" that the "members" of the Bank were all citizens of Pennsylvania, a fact that the Bank had alleged to support diversity jurisdiction. ${ }^{163}$ Thus, corporations whose protection was less important as a matter of national policy were effectively barred from the federal courts. ${ }^{164}$ And although the Court held that a corporation could be considered as a "company of individuals" for jurisdictional purposes, it did not suggest that it would pierce the corporate veil and look through to the individuals comprising the corporation for any purposes that were not incidental to the corporation's existence-such as spending money on a political campaign. Indeed, any such a holding would have been odd, because Justice Johnson, while sitting on the district court, had emphatically endorsed the view that "individual[s] [are] so totally sunk in their corporate state of existence" that they could not transmit rights to the corporation. ${ }^{165}$ Thus, Justice Scalia's view that "the individual person's right to speak include[d] the

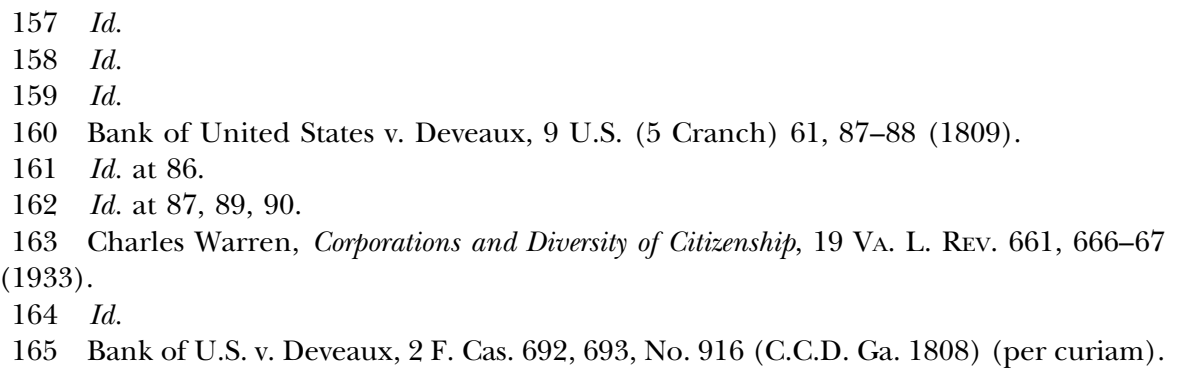


right to speak in association with other individual persons" appears incorrect as a historical matter. ${ }^{166}$

And even if Deveaux could be construed in support of that view, it was overruled thirty-five years later in Louisville, Cincinnati, $\mathcal{E}$ Charleston Rail-road Co. v. Letson. ${ }^{167}$ There, the Court held that a corporation could sue in its own name, and its residence was its chartering state. ${ }^{168}$ The Court also went out of its way to state that the late Chief Justice Marshall had "repeatedly expressed regret" about the Deveaux decision, and that he wished the outcome had been different. ${ }^{169}$ After Letson, a corporation was treated as an entity for the sake of federal jurisdiction, and the Court explicitly rejected the notion that stockholders could assert their own, individual, rights through the corporation. As the Court put it in Marshall v. Baltimore E Ohio Railroad Co. in 1853, nine years later: "[F] or all the purposes of acting, contracting, and judicial remedy, [the stockholders] can speak, act, and plead, only through their representatives or curators [i.e., the board of directors]." 170

As Deveaux, Letson, and Marshall made plain, a corporation could only exercise rights in its corporate name. If we pierce the corporate veil and argue that the corporation can exercise the personal rights of its individual stockholders, we must assume that all these stockholders would want to express the same views on the particular topic at hand (unless the corporation is entitled to express more than one view on a particular matter). But, as the Marshall Court observed, stockholders are "numerous unknown and everchanging associates," and may dissent from the majority view. ${ }^{171}$ Justice Scalia's argument in his Citizens United concurrence that corporations should be regarded as associations of individuals for the purpose of exercising First Amendment rights thus seems to be at odds with historical understandings of the corporation and the reality of diverse stockholder ownership, including the early understanding that it was not credible to equate the views of the corporation to those of its diverse and changing stockholders.

\section{B. Judicial Treatment of Corporations Before the Civil War}

We now move to a more general discussion of judicial decisions affecting corporations in the antebellum period. As James Willard Hurst has written, "[f] rom the first years in which we made much use of the corporate device, statute law defined the . . . basic terms on which the legal order would legitimate use of the corporation." ${ }^{172}$ The rights of corporations were not some-

166 Citizens United v. FEC, 558 U.S. 310, 392 (2010) (Scalia, J., concurring) (emphasis omitted).

16743 U.S. (2 How.) 497, 555 (1844).

168 Id. at 559.

$169 I d$. at 555.

17057 U.S. (16 How.) 314, 328 (1853).

$171 \mathrm{Id}$.

172 Hurst, supra note 16, at 122 (emphasis added). 
thing for courts to define; they were for the legislature to define. ${ }^{173}$ "This was legislative, not judicial, business. It was so for reasons of constitutional force; only to the popularly elected assemblies did we concede authority to deal with the social balance of power" that would be affected by corporations. ${ }^{174}$ In the federal courts-that is, the courts of the government that did not generally charter corporations-“" $[\mathrm{a}]$ substantial body of . . . constitutional law" eventually emerged concerning the rights and limits on business corporations, but this body of law developed under the later "broad language" of the Fourteenth Amendment, and never once related to questions of corporate political speech. ${ }^{175}$

Before the Civil War, courts did impinge on state legislatures' abilities to regulate corporations in limited ways. Two important early cases relate to universities. At issue in Trustees of the University of North Carolina v. Foy was a state statute that purported to confiscate all the property of the University of North Carolina that had escheated to that university. ${ }^{176}$ The North Carolina Supreme Court held that this statute was unconstitutional, and based its decision in part on the "law of the land" clause from the North Carolina Bill of Rights, which provided that "no freeman ought to be taken, imprisoned or disseized of his freehold, liberties or privileges, or outlawed or exiled, or in any manner destroyed or deprived of his life, liberty or property, but by the law of the land." 177 The state conceded the legislature would have had no power to confiscate property from an individual, but denied that corporations had the same protection. The court disagreed: it held that it was "clear" that the law of the land clause "was intended to secure to corporations as well as to individuals the rights therein enumerated." 178

Following Foy, "the law of the land clauses of the states generally seemed destined to become bulwarks for vested corporate rights." 179 This progress was arrested, however, by the famous Dartmouth College decision, which held that the legislature of New Hampshire could not force the college to become a public institution. ${ }^{180}$ The Court's decision, however, was based on the Con-

$173 I d$.

$174 I d$. at 123

175 Id. at 114

1765 N.C. (1 Mur.) 57, 57-58 (1805).

177 Id. at 62 (quoting N.C. Const. of 1776, Declaration of Rights, art. XII).

178 Id. This supposed "clarity" was based on a tenuous distinction between "liberties" in the first part of the clause and "liberty" in the latter part:

That this clause was intended to secure to corporations as well as to individuals the rights therein enumerated, seems clear from the word "liberties," which peculiarly signifies those privileges and rights which corporations have by virtue of the instruments which incorporate them, and is certainly used in this clause in contradistinction to the word "liberty," which refers to the personal liberty of the citizen.

Id.

179 Howard Jay Graham, The "Conspiracy Theory" of the Fourteenth Amendment: 2, 48 YaLE L.J. 171, 172 (1938).

180 Trs. of Dartmouth Coll. v. Woodward, 17 U.S. (4 Wheat.) 518, 712 (1819). 
tracts Clause, not the Due Process Clause. ${ }^{181}$ The purpose of the Contracts Clause, Chief Justice Marshall held, was to "restrain the legislature in future from violating the right to property." 182 And the charter of the college was "plainly a contract to which the donors, the trustees, and the crown, (to whose rights and obligations New-Hampshire succeeds,) were the original parties. . . . It is a contract for the security and disposition of property."183 But, in holding that the Trustees could enforce this charter like a contract, the Court emphasized the limited rights possessed by a corporation:

A corporation is an artificial being, invisible, intangible, and existing only in contemplation of law. Being the mere creature of law, it possesses only those properties which the charter of its creation confers upon it, either expressly, or as incidental to its very existence. These are such as are supposed best calculated to effect the object for which it was created. ${ }^{184}$

Marshall's holding is consistent both with contemporary practice and the descriptions of the corporation by Coke, Blackstone, and Kyd, described in Part IV. And this famous description of a corporation-that it is an "artificial being, invisible, intangible, and existing only in contemplation of law"was reaffirmed scores of times before the Civil War. ${ }^{185}$ (Indeed, it was also reaffirmed scores of times after the Fourteenth Amendment was enacted, which is powerful evidence that the Fourteenth Amendment was not seen as changing the rights of corporations, as we discuss further in the next Part. ${ }^{186}$ ) Given the weight of this history, Justice Scalia's contention that there is no evidence that corporations were not permitted to participate freely in the political process seems to ignore the most prominent source of public understanding.

In fact, even as to property rights closely connected to the business interests of a corporation, the courts were reluctant to give corporations constitutional protections. In the 1837 case of Proprietors of Charles River Bridge $v$. Proprietors of Warren Bridge, the Court ruled that the Massachusetts legislature had the power to grant a company a charter to build a new, free, bridge over the Charles River, even though the bridge would interfere with a for-profit

\footnotetext{
181 Id. at 627.

$182 I d$. at 628.

183 Id. at $643-44$.

184 Id. at 636; William W. Bratton, Jr., The New Economic Theory of the Firm: Critical Perspectives from History, 41 STAN. L. Rev. 1471, 1505 (1989) ("Since the corporation is not a natural person it has no ability to formulate its own purposes and follow them. Less than a person, it is only a means to prescribed ends.").

185 Dartmouth, 17 U.S. (4 Wheat.) at 636 . The phrase "existing only in contemplation of law" appears first in the reporter's notes in Bank of United States v. Deveaux, 9 U.S. (5 Cranch) 61, 73 (1809) (emphasis omitted). It was then used simultaneously in Chief Justice Marshall's Dartmouth decision and in the Connecticut case of Bulkley v. Derby Fishing Co., 2 Conn. 252, 260 (1817), both of which were published in November 1817. A Westlaw search for "existing only in contemplation of law" returns thirty-four cases involving corporations between Dartmouth and 1860 .

186 According to a Westlaw search, the phrase "existing only in contemplation of law" appears in over fifty cases involving corporations between 1860 and 1900 .
} 
bridge nearby, the Warren Bridge. ${ }^{187}$ The Warren Bridge company's charter did not grant an explicit monopoly on traffic over the Charles, and so the Warren Bridge argued that it received such a monopoly by implication: it held its franchise through a contract with the Commonwealth of Massachusetts, and the legislature could not unilaterally destroy the value of its franchise. The Court rejected this argument, applying a well-settled rule of decision that grants to private corporations affecting the public interest were to be narrowly construed. ${ }^{188}$ Thus, Chief Justice Taney wrote, "[t]hat a corporation is strictly limited to the exercise of those powers which are specifically conferred on it, will not be denied. The exercise of the corporate franchise being restrictive of individual rights, cannot be extended beyond the letter and spirit of the act of incorporation." 189

The Charles River Bridge case shows that states retained the power to regulate their corporations, not the courts. And two years later, the Court (again speaking through Chief Justice Taney) affirmed a state's power to regulate foreign corporations in Bank of Augusta $v$. Earle. ${ }^{190}$ The question was whether a corporation that was chartered in one state could validly enter into contracts in another state. The Court quoted Dartmouth College's statement that a corporation was a "mere creature of the law" and only had properties that were expressly given it in the charter or "incidental to [the corporation's] very existence."191 The Court ruled that, under principles of comity, a corporation chartered in one state could enter into binding contracts in another state. But the Court also recognized a restriction on this principle: if a state "indicates that contracts which derive their validity from its comity are repugnant to its policy, or are considered as injurious to its interests," it need not give effect to those contracts. ${ }^{192}$

Charles River Bridge and Bank of Augusta made clear that a corporation was under the control of its chartering state and any state where it conducted business. Lawyers for business corporations chafed against these restrictions and challenged state powers over their clients in court. ${ }^{193}$ They appeared poised for a breakthrough in the 1850s, when the New York Court of Appeals handed down two decisions that accepted that vested property rights were protected by the due process clause of the state constitution. In Westervelt $v$. Gregg, the Court of Appeals ruled that a husband had a vested interest in a legacy bequeathed to his wife before the enactment of the Married Women's Property Act in 1848. ${ }^{194}$ And in Wynehamer v. People, the Court of Appeals ruled that a state prohibition statute could not criminalize the possession and

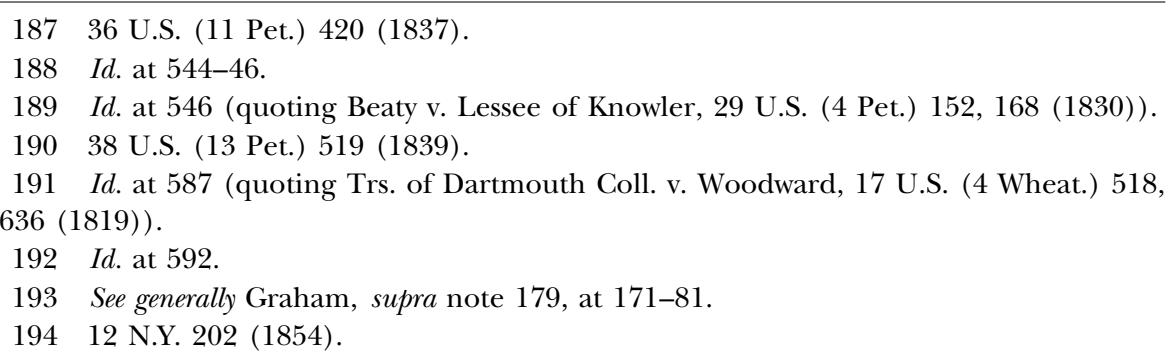


sale of alcohol acquired before the statute went into effect. ${ }^{195}$ About the same time, the United States Supreme Court held for the first time that vested property rights were protected by the Due Process Clause of the Federal Constitution. ${ }^{196}$

Nevertheless, the use of the Due Process Clause to protect the rights of corporations was set back when the New York Court of Appeals refused to apply the Clause in favor of out-of-state insurance companies who were challenging a tax levied on all fire premiums to support the New York Fire Department. ${ }^{197}$ It may be that the court was motivated by criticism of Wynehamer. ${ }^{198}$ And criticism of Chief Justice Taney's infamous decision in Dred Scott, which also relied on a theory of substantive due process, may have contributed to the limited success of later efforts of corporations to obtain the protections of due process clauses. ${ }^{199}$ But it appears that shortly before the enactment of the Fourteenth Amendment, corporations still had not even generally obtained constitutional protections of their property rights and remained subject to restrictions on their conduct by their chartering states and the jurisdictions in which they operated.

\section{General Incorporation Statutes and External Regulation}

We now examine the law under which corporations were chartered. As we have described, until the early years of the nineteenth century, all corporations were created through special charters. These corporations were few in number and subject to tight restrictions on their business activities. Therefore, there was little need for external regulation. With the exception of transportation and finance, "state regulation was rather random and planless." 200 And not only was regulation haphazard, there was little money to enforce external regulation, so private citizens usually had to enforce what rules there were in a lawsuit or through a complaint to a state official. ${ }^{201} \mathrm{But}$, because corporations were far weaker than they are now, the failings of state regulation were not a critical concern.

All this began to change in the nineteenth century with the move toward general incorporation statutes. Under these statutes, any organization that fulfilled the statutory requirements could be incorporated without petitioning for a special charter. Just as business corporations postdated other forms of corporation, so general incorporation statutes were initially enacted for

19513 N.Y. 378 (1856).

196 Bloomer v. McQuewan, 55 U.S. (14 How.) 539, 553 (1852).

197 Graham, supra note 179 , at 177-78.

198 Id. The Court of Appeals cast doubt on Wynehamer ten years later. See Metro. Bd. of Excise v. Barrie, 34 N.Y. 657, 668 (1866) (holding that state statute restricting liquor sales was a proper exercise of the police power, and disapproving the "inconsiderate dicta of some of the judges in the case of Wynehamer v. The People").

199 Dred Scott v. Sandford, 60 U.S. (19 How.) 393 (1857); see Graham, supra note 179, at 178 n.42.

200 Friedman, supra note 100 , at 125.

$201 I d$. at $128-29$. 
the benefit of religious and charitable organizations. ${ }^{202}$ The first general incorporation statute for businesses was passed by New York in 1811, but only covered manufacturing companies, and was not imitated by other states. ${ }^{203}$ In the 1830s, Pennsylvania and Connecticut enacted their general incorporation laws. These laws were copied by other states, and by 1859 , twenty-four of the thirty-eight then-existing states or territories had general incorporation statutes. ${ }^{204}$

The rise of general incorporation statutes, and the corresponding increase in the number of corporations, did not mean that states relinquished their abilities to regulate corporations. For starters, many states did not permit all corporations to take advantage of their general incorporation statutes. Certain types of corporation, such as railroads and banks, still required special charters. ${ }^{205}$ It was no accident that these activities had the greatest impact on interstate commerce, and thus were the most difficult to regulate. States continued to issue special charters for these types of corporations until stronger federal regulation emerged in these industries in the 1930s. ${ }^{206}$ The new incorporation regime in the first half of the nineteenth century was not entirely liberal. Most state legislatures adopted constitutional or statutory rules allowing them to change or revoke corporate charters at will, and courts continued to construe the rights conferred by corporate charters narrowly. ${ }^{207}$

Originalists also have to struggle with more specific aspects of the ruling in Citizens United. Under McCain-Feingold, the government did not bar corporations from engaging in any political activity. To the contrary, corporations were authorized to use corporate resources to establish political action committees that could solicit voluntary contributions from employees and stockholders, which could then be used by the corporate PAC to make political expenditures, including ones expressly advocating the election or defeat of a political candidate. ${ }^{208}$ Remember that as of 1791, corporations were legislatively chartered and could only conduct such activities as were specifically enumerated in their charters. But even after corporations were given more leeway under general incorporation statutes, corporate law limited the freedom of corporations to act in many ways without unanimous consent of the stockholders. As of 1868 and even into the twentieth century, for example, the general rule was that a corporation could not merge with another

\footnotetext{
202 Hurst, supra note 16, at 134.

203 See Hamill, supra note 13, at 101.

204 Id. at $101-03$.

205 Id. at $105-06$.

206 Id. at $146-59$.

207 SeAvoy, supra note 62, at 240-42. This restriction on corporate rights was paralleled by the judicial doctrine that charters were to be narrowly construed. Id.

2082 U.S.C. $\S 441 b$ (b) (2) (2006) (defining "contribution" to exclude contributions to "separate segregated fund[s]" established by corporations, i.e., PACs); see also 11 C.F.R. $\S 114.2$ (2009) (setting out regulations for contributions by corporations, and by and to their PACs).
} 
corporation without unanimous consent. ${ }^{209}$ Viewed through that originalist prism, McCain-Feingold can be viewed as simply a requirement that the corporation only make such contributions as its stockholders voluntarily authorize it to make, by using a PAC as the collection mechanism for that purpose. That seems a far lesser constraint than barring any political contributions unless unanimous consent was obtained from all stockholders.

As important, states countered the potentially negative effects of the growth in the number of corporations under general statutes by strengthening the external regulation of corporations. ${ }^{210}$ One scholar has written that in the 1850s "the focus of American legislation slowly began to shift from promotion of economic development towards greater regulation of that development." 211 States began to create regulatory commissions or special departments within state governments to control corporations. ${ }^{212}$ The first regulatory commission in New York, the Bank Commission, was established in 1829. ${ }^{213}$ An insurance commission followed. New York did not establish a railroad commission, although other states, such as Rhode Island in 1839, did. ${ }^{214}$ These methods of state control over corporations to some extent made up for the absence of federal regulation, which was hindered in large part by the dispute over slavery. ${ }^{215}$ As we discuss later, after the Civil War, federal regulation over corporations increased substantially. ${ }^{216}$

The general incorporation statutes were also comparatively restrictive by modern standards. ${ }^{217}$ For example, general incorporation acts set restrictions on capitalization, and businesses in the mid-nineteenth century would still need to obtain special charters to avoid these restrictions. ${ }^{218}$ "To the

209 See, e.g., Norwood P. Beveridge, Interested Director Contracts at Common Law: Validation Under the Doctrine of Constructive Fraud, 33 Loy. L.A. L. REv. 97, 109 (1999) (noting that corporate law required unanimous consent of stockholders for "extraordinary transactions” (citing People v. Ballard, 32 N.E. 54, 59 (N.Y. 1892); Abbot v. Am. Hard Rubber Co., 33 Barb. 578, 590-93 (N.Y. App. Div. 1861)); Bayless Manning, The Shareholder's Appraisal Remedy: An Essay for Frank Coker, 72 YALE L.J. 223, 249 (1962) ("Old rules requiring unanimity for action by the homely small enterprise could no longer work for the large impersonal collectivity [in the late nineteenth century.]"); see also, e.g., Geddes v. Anaconda Copper Mining Co., 254 U.S. 590, 595-96 (1921) ("It is, of course, a general rule of law [that directors could not sell all the assets of a company without unanimous stockholder consent].”).

210 See, e.g., Hovenkamp, supra note 135, at 1627-33 (noting that general incorporation acts shortly preceded state regulation of industries); see also David Millon, Theories of the Corporation, 1990 Duke L.J. 201, 206 (noting that states that adopted general incorporation acts made charters available upon "submission to standardized substantive regulations").

211 Michael Les Benedict, Laissez-Faire and Liberty: A Re-Evaluation of the Meaning and Origins of Laissez-Faire Constitutionalism, 3 Law \& Hist. Rev. 293, 327 (1985).

212 Seavoy, supra note 62, at 242.

$213 I d$. at 243.

214 Friedman, supra note 100, at 334; SEAvoy, supra note 62, at 244.

215 Seavoy, supra note 62, at 252.

216 See infra Section VI.D.

217 See Hurst, supra note 16, at 29.

218 Id.; see generally SEAVOY, supra note 62, at 199-224. 
end of the nineteenth century corporation law often built some regulations into corporate structure to protect general social interests." ${ }^{19}$ As we discuss further below, general incorporation statutes only became more liberal around the turn of the century, when New Jersey led the way in removing restrictions on cross-shareholdings and foreign business dealings. ${ }^{220}$

\section{Treatises}

Finally, we examine the corporate law treatises that were published before the Civil War. If we were to find support for the view that nineteenth century corporations had broad expressive rights, we might expect to find it in the hornbooks. But these too are silent, and what they say emphasizes that corporations were not rights-bearers like human beings.

In 1826, Chancellor James Kent published his Commentaries on American Law, which remained in print throughout the century. He noted that a corporation could only carry out those acts that it was authorized to perform in its charter or those that were "inseparably incident to [it]."221 Kent's list of incidental powers is similar to Coke's, Blackstone's, and Kyd's:

1. To have perpetual succession, and, of course, the power of electing members in the room of those removed by death or otherwise; 2 . To sue and be sued, and to grant and to receive by their corporate name; 3 . To purchase and hold lands and chattels; 4 . To have a common seal; 5 . To make by-laws for the government of the corporation; 6 . The power of amotion, or removal of members. ${ }^{222}$

According to Kent: "A corporation being merely a political institution, it has no other capacities or powers than those which are necessary to carry into effect the purposes for which it was established. A corporation is incapable of a personal act in its collective capacity." ${ }^{223}$ This casts doubt on Justice Scalia's contention that the Founders would have seen a corporation as an association of individuals who were permitted to exercise speech rights in corporate form. Kent also stressed that a corporation's powers were strictly construed:

The modern doctrine is to consider corporations as having such powers as are specifically granted by the act of incorporation, or as are necessary for the purpose of carrying into effect the powers expressly granted, and as not having any other. The Supreme Court of the United States declared this obvious doctrine, and it has been repeated in the decisions of the state courts. No rule of law comes with a more reasonable application, considering how lavishly charter privileges have been granted. As corporations are the mere creatures of law, established for special purposes, and derive all their powers from the acts creating them, it is perfectly just and proper that they should be obliged strictly to show their authority for the business they

219 Hurst, supra note 16, at 161.

220 Id. at 147.

2212 James Kent, Commentaries on American Law *277 (1826).

222 Id. at *277-78.

$223 I d$. at $* 279$. 
assume, and be confined in their operations to the mode, and manner, and subject-matter prescribed. ${ }^{224}$

The 1832 treatise of Joseph Angell, the Rhode Island legal scholar and court reporter, and Samuel Ames, the Chief Justice of Rhode Island, is consistent with Kent's Commentaries. ${ }^{225}$ For a definition of a corporation, Angell and Ames looked to Chief Justice Marshall's opinion in Dartmouth College: "A corporation,' says the Chief Justice, 'is an artificial being, invisible, intangible, and existing only in contemplation of law." 226 After reviewing Blackstone and Kyd, they compare a corporation to natural persons: "A corporation . . . is a political institution merely, and it has, therefore, no other capacities than such as are necessary to effect the purpose of its creation." 227

Later in their work, Angell and Ames discussed further the limitations of a corporate charter, which was an "executed contract between the government and the corporators." 228 But, to avoid the strictures of the contracts clause,

it has become usual for legislatures, in acts of incorporation for private purposes, to reserve to themselves a power to alter, modify, or repeal the charter at their pleasure; and as the power of modification and repeal is thus made a qualifying part of the grant of franchises, the exercise of that power cannot, of course, impair the obligation of the grant. ${ }^{229}$

The corporation's property, Angell and Ames stated, was not entirely at the mercy of the legislature. Rather,

[a]s all or any of the property of a citizen may, upon just compensation made, be taken, and applied to the use of the public, so all property belonging to a corporation must in like manner be held liable to the same eminent domain, or peculiar power of the government. ${ }^{230}$

But there is no suggestion that a corporation shared the political rights of human citizens as well as their property rights. ${ }^{231}$

$224 I d$. at $* 298-99$ (footnotes omitted).

225 Angell \& Ames, supra note 135. Angell's and Ames's treatise remained in print throughout the nineteenth century, and the 1871 twelfth edition was edited by Oliver Wendell Holmes.

226 Id. at 2 (quoting Trs. of Dartmouth Coll. v. Woodward, 17 U.S. (4 Wheat.) 518, 636 (1819)) .

227 Id. at 3.

$228 I d$. at 503.

$229 I d$. at 504.

230 Joseph K. Angell \& Samuel Ames, Treatise on the Law of Private Corporations AgGregAte 166 (John Lathrop ed., 10th ed. 1875) (emphasis omitted); see also id. $\$ 477$, at 495 ("[T] he [corporate] franchise is not to be distinguished from other property; every kind of property being equally protected by the constitution.").

231 Just as the conception of the corporation in America did not change before the 1860s in America, nor did it change in England. The first treatise on corporations (as opposed to joint-stock companies) since Kyd's was published by James Grant in 1850. Consistent with the earlier English and American authorities, Grant wrote that a corporation "is in fact an abstraction of law, having no existence or power of action but what the law gives it." James Grant, A Practical Treatise on the Law of Corporations 3 (1850). 


\section{The Understanding of Corporations as of the Adoption of the Fourteenth Amendment}

As we have discussed, the rule as of the adoption of the Fourteenth Amendment was that stated by Chief Justice Marshall in Dartmouth College: that a corporation "possesse[d] only those properties which the charter of its creation confers upon it," and that it had no "political power, or a political character." 232 Although there were some discrete cases when corporations were allowed to assert constitutional rights, those cases involved government action that threatened a core property interest critical to the corporation's ability to conduct the business it was chartered to conduct. ${ }^{233}$ We next examine whether the Fourteenth Amendment was understood to change this understanding of corporate rights and to accord the same rights to them as persons born or naturalized in the United States.

\section{A. The Text}

As we did with the First Amendment, we start with the text. The first section of the Fourteenth Amendment provides that:

All persons born or naturalized in the United States and subject to the jurisdiction thereof, are citizens of the United States and of the State wherein they reside. No State shall make or enforce any law which shall abridge the privileges or immunities of citizens of the United States; nor shall any State deprive any person of life, liberty, or property, without due process of law; nor deny to any person within its jurisdiction the equal protection of the laws. ${ }^{234}$

This text does not suggest in any way that corporations are persons for the purposes of the Amendment's clauses protecting "citizens" and "persons." 235 Because corporations are not citizens, the only textual basis for the argument that corporations should be protected by the Fourteenth Amendment comes from the use of the word "person" in the due process and equal protection clauses. But the argument that the use of the word "person" rather than "citizen" was a deliberate attempt to bring corporations under the protection of the Fourteenth Amendment has been refuted, as there is

Where the corporation derived its corporate status from a charter (as opposed to common law or prescription), it could not "pursue any other objects than those specified in its charters." Id. at 13 .

232 Trs. of Dartmouth Coll. v. Woodward, 17 U.S. (4 Wheat.) 518, 636 (1819).

233 E.g., Trs. of Univ. of N.C. v. Foy, 5 N.C. (1 Mur.) 57 (1805) (holding invalid an act transferring property from the University of North Carolina to the state).

234 U.S. Const. amend. XIV, § 1.

235 See, e.g., Jess M. Krannich, The Corporate "Person": A New Analytical Approach to a Flawed Method of Constitutional Interpretation, 37 Loy. U. CHI. L.J. 61, 101 (2005) ("It is beyond debate that the Fourteenth Amendment does not apply to corporations on its face."). 
no historical evidence supporting that intention. ${ }^{236}$ And, based on the text of the Fourteenth Amendment alone, one would likely conclude that corporations are not persons: the first clause of the Amendment suggests that all "persons" must be capable of being "born" or "naturalized." 237 We suspect that Justice Scalia himself would rightly cast ridicule on the idea that a legislature gave "birth" to a domestic corporation or "naturalized" a foreign one by allowing it to incorporate in the United States.

Any argument, then, that corporations had the same rights as natural persons must be based on the historical notion of corporate personhood in 1868, not the text of the Fourteenth Amendment. We therefore proceed to the second stage of Justice Scalia's inquiry and look to the historical conception of the rights of corporations at the time of the ratification of the Fourteenth Amendment and whether that Amendment somehow altered it.

\section{B. Case Law After the Fourteenth Amendment}

By the time of the adoption of the Fourteenth Amendment, the concept that a business corporation could be deemed a legal person for certain purposes was established in American law. ${ }^{238}$ So it was unsurprising that lawyers for business corporations continued to argue that their clients should be afforded the rights of citizens. In Paul v. Virginia in 1868, an insurance company challenged a Virginia statute that provided that any foreign insurer doing business in Virginia should have to deposit with the state treasurer bonds issued by the state or by state residents of at least $\$ 30,000$ in value. ${ }^{239}$ The insurer argued that Virginia's regulation violated the Privileges and Immunities Clause of Article IV, Section 2, of the Constitution. The Court rejected this challenge easily:

The answer which readily occurs to the objection founded upon the first clause consists in the fact that corporations are not citizens within its meaning. The term citizens as there used applies only to natural persons, members of the body politic, owing allegiance to the State, not to artificial persons created by the legislature, and possessing only the attributes which the legislature has prescribed. ${ }^{240}$

Even though, as we have described above, general incorporation statutes were by then commonplace, the Court noted that "a grant of corporate existence is a grant of special privileges to the corporators, enabling them to act

236 Graham, supra note 179, at 194 ("Section One was not designed to aid corporations, nor was the distinction between 'citizens' and 'persons' conceived for their benefit.") (emphasis omitted); see also Bloch \& Lamoreaux, supra note 1, at 6-10.

237 As Justice Black put it in his dissent in Connecticut General Life Insurance Co. v. Johnson, "[c] ertainly a corporation cannot be naturalized." 303 U.S. 77, 88 (1938) (Black, J., dissenting).

238 Graham, supra note 179, at 194; see, e.g., Marshall v. Balt. \& Ohio R.R. Co. 57 U.S. (16 How.) 314, 328 (1853) (considering a corporation a citizen of its chartering state for purposes of federal diversity jurisdiction).

23975 U.S. (8 Wall.) 168 (1868).

$240 I d$. at 177. 
for certain designated purposes as a single individual, and exempting them (unless otherwise specially provided) from individual liability."241 The Court thus reaffirmed Bank of Augusta v. Earle. ${ }^{242}$ This evidence suggests that the Fourteenth Amendment had not changed the constitutional status of corporations.

Nevertheless, the Fourteenth Amendment did not leave the rights of corporations completely unaffected. Rather, as respected scholars such as Professors Bloch, Lamoreaux, and O'Kelley have shown, corporations were able to use the protection of the Fourteenth Amendment to ensure that they had the same protections that individuals had when conducting business, when such protections were necessary and incidental to their business. Thus, from the 1880 s to the mid-twentieth century, the Court adhered to a construction of the Fourteenth Amendment whereby corporations were entitled to property rights, but were not deemed to have liberty interests. ${ }^{243}$

This construction of the Fourteenth Amendment was largely the work of Justice Stephen Field, who served on the Supreme Court between 1863 and 1897. Justice Field rode circuit in California, alongside a local federal judge, and heard two important suits involving the right of California to tax railroads. Both suits involved the California Constitution of 1879's imposition of discriminatory taxation on railroads. Under the California Constitution, owners of property were generally permitted to deduct liens secured on their property from its valuation for tax purposes. ${ }^{244}$ The State did not lose tax revenue this way: it taxed the lienholders directly. ${ }^{245}$ But, railroads were specifically not permitted to deduct liens or mortgage interests, and each county was permitted to tax the property of the railroad within the county at its "actual value." 246 The California railroads refused to pay the additional tax, claiming that it was unconstitutional under the Fourteenth Amendment. ${ }^{247}$

The counties that were losing tax revenue filed suit in federal court. The suits were consolidated into two: County of San Mateo v. Southern Pacific

$241 I d$. at 181. This casts doubt on the thesis that the rise of general incorporation statutes spelled the end of the concession theory of the corporation. See O'Melinn, supra note 99 , at 229-40.

242 Paul, 75 U.S. (8 Wall.) at 178-82. Three years later, the opinion in Bank of Augusta was described as "very able and satisfactory" in an 1875 edition of Joseph Angell's and Samuel Ames's treatise (originally published in 1831), indicating that academics likewise considered it still good precedent. Angell \& SAmuel, supra note 230, § 273, at 264.

243 See, e.g., Nw. Nat'l Life Ins. Co. v. Riggs, 203 U.S. 243, 255 (1906) ("The liberty referred to in [the Fourteenth] Amendment is the liberty of natural, not artificial persons."); Hale v. Henkel, 201 U.S. 43 (1906) (holding that a corporation was entitled to the Fourth Amendment's protection against unreasonable searches and seizures, but was not entitled to the Fifth Amendment's protection against self-incrimination); see also Bloch \& Lamoreaux, supra note 1 , at 30.

244 Cal. Const. of 1879 , art. XIII, $\S 4$.

245 Id.

$246 I d$. art. XIII, $\$ 10$.

247 O’Kelley, supra note 9, at 1353-54. 
Railroad Co. ${ }^{248}$ and County of Santa Clara v. Southern Pacific Railroad Co. ${ }^{249}$ In the wide-ranging opinion in San Mateo, Justice Field rejected numerous arguments by the County that the discriminatory tax should be sustained. First, Justice Field held that the Fourteenth Amendment "impose[d] a limitation upon the exercise of all the powers of the state which can touch the individual or his property, including among them that of taxation."250 Thus, the state could not tax individuals unequally. But next, Justice Field had to show that the corporation should be considered an individual for the purposes of the Fourteenth Amendment's guarantee of property rights. Justice Field rejected the County's argument that the Fourteenth Amendment was designed simply to protect freedmen, but ruled that its guarantees encompassed everyone, even a "master of millions." 251 And, because corporations were so important in all aspects of modern life, "[i]t would be a most singular result if a constitutional provision intended for the protection of every person ... should cease to exert such protection the moment the person becomes a member of a corporation." 252

Field set out a clear process of reasoning for determining which constitutional rights were possessed by corporations-a vision that Professor O'Kelley has termed "the Field rationale." 253 A corporation had constitutionally protected property rights because " $[\mathrm{t}] \mathrm{o}$ deprive the corporation of its property . . . is, in fact, to deprive the corporators of their property." 254 Thus, the corporation's property was constitutionally protected for the sake of carrying on its business. But "the same clause of the . . . amendment [protecting life and liberty] does not apply to corporations, because ... the lives and liberties of the individual corporators are not the life and liberty of the corporation." ${ }^{255}$ In Professor O'Kelley's words, "the constitutional rights of a business corporation ... must be coextensive with the rights that its shareholders would enjoy if they had chosen to conduct their business in an unincorporated form." 256 But, "only natural persons can assert natural liberties, as opposed to rights necessary to protect property." 257

The Southern Pacific Railroad Company thus prevailed in San Mateo. ${ }^{258}$ In Santa Clara, Justice Field again ruled that California's railroad companies could not be required to pay the discriminatory tax. ${ }^{259}$ Santa Clara was then

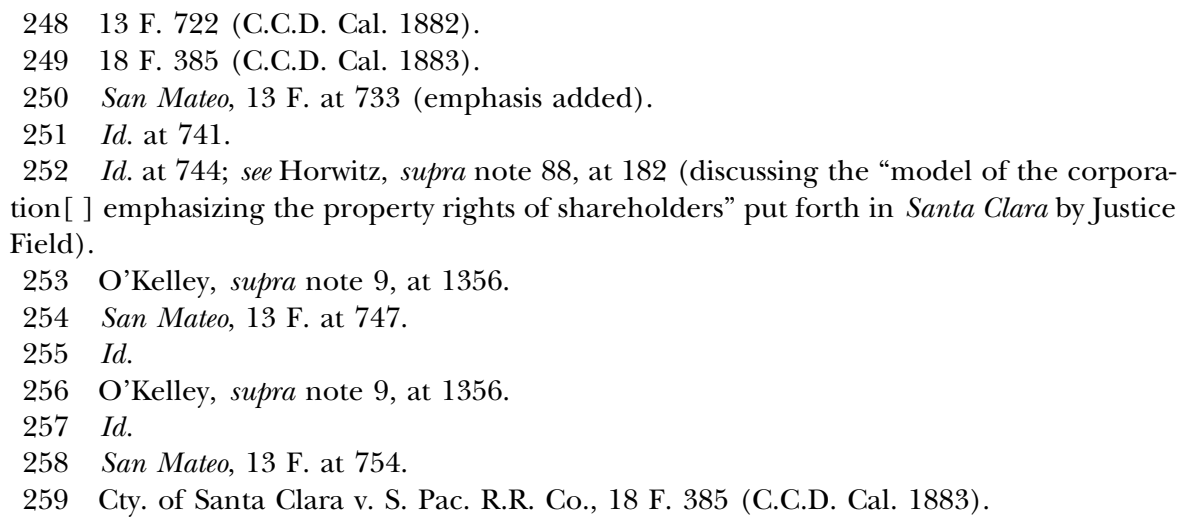


appealed to the Supreme Court, where the Court held for the railroads on extremely narrow grounds-that the cost of fences separating the tracks from neighboring land had been erroneously included in the assessment. ${ }^{260}$ It seems that the Court chose this ground deliberately so that "there [would] be no occasion to consider the grave questions of constitutional law upon which the case was determined below."261 But despite this, Santa Clara is famous for its supposed holding that the Fourteenth Amendment protects corporations. As Professors Bloch and Lamoreaux explain, the Supreme Court reporter, J.C. Bancroft Davis, wrote at the start of the opinion a paraphrase of the pre-argument statement of Chief Justice Waite that " $[\mathrm{t}]$ he court does not wish to hear argument on the question whether the [Equal Protection Clause of] the Fourteenth Amendment ... applies to these corporations. We are all of opinion that it does." 262

This cursory dictum showing support by the Supreme Court for Justice Field's holdings below in the San Mateo and Santa Clara cases later became law when it was cited and relied on by Justice Field in other cases. ${ }^{263}$ Thus, in an 1888 case involving Pennsylvania's license tax on foreign corporations having an office in the Commonwealth, Justice Field wrote, for a unanimous Court: "Under the designation of person [in the Fourteenth Amendment] there is no doubt that a private corporation is included." 264 The following year, in a railroad case, Justice Field held-relying on Santa Clara and his ruling the previous year-that "corporations are persons within the meaning of [the Equal Protection Clause]."265

Thus, the Field rationale took hold: a corporation should have "such rights ... coextensive with the rights that its shareholders would enjoy if they had chosen to conduct their business in an unincorporated form." 266 The emphasis we added is important because Field's reasoning applied only to those constitutional property rights essential to conducting business. ${ }^{267}$ Even then, this did not mean that corporations were necessarily successful in asserting their property rights. As Professors Bloch and Lamoreaux observe, Justice Field regularly upheld state laws regulating domestic corporations, provided that they affected corporations equally. ${ }^{268} \mathrm{He}$ also upheld state laws that discriminated against foreign corporations. ${ }^{269}$ The 1888 and 1889 cases cited above are precisely in point: there, Field sustained Pennsylvania's

\footnotetext{
260 Santa Clara Cty. v. S. Pac. R.R. Co., 118 U.S. 394 (1886).

261 Id. at 411.

262 Id. at 396; see Bloch \& Lamoreaux, supra note 1, at 11.

263 Bloch \& Lamoreaux, supra note 1, at 12.

264 Pembina Consol. Silver Mining \& Milling Co. v. Pennsylvania, 125 U.S. 181, 189 (1888).

265 Minneapolis \& St. Louis Ry. Co. v. Beckwith, 129 U.S. 26, 28 (1889).

266 O'Kelley, supra note 9, at 1356 (emphasis added).

267 See, e.g., Cty. of San Mateo v. S. Pac. R.R. Co., 13 F. 722, 747 (C.C.D. Cal. 1882)

("The prohibition against the deprivation of life and liberty in the same clause of the fifth amendment does not apply to corporations .....").

268 Bloch \& Lamoreaux, supra note 1, at 12.

$269 I d$. at 16.
} 
license tax on foreign corporations, ${ }^{270}$ and an Iowa statute providing for double damages on a strict liability basis when a train killed livestock. ${ }^{271}$ The only restriction on a state's regulation of foreign corporations was that a state was not allowed to interfere with interstate commerce-but interstate commerce was defined so narrowly that this rarely posed an obstacle. ${ }^{272}$

And the flipside to the Field rationale was that corporations did not have liberty rights. Thus, in Northwestern National Life Insurance Co. v. Riggs, in 1906, the Court sustained a Missouri statute that prevented a life insurer from denying death benefits on the ground that the insured had made misrepresentations when taking out the policy, unless the misrepresentations were material to the cause of death. ${ }^{273}$ The Court held: "The liberty referred to in [the Fourteenth] Amendment is the liberty of natural, not artificial persons." 274

Corporations soon became repeat players before the Court, because they had the wealth to press cases to the top. ${ }^{275}$ And, in the Lochner era, they were often successful. In Professor Mayer's words, "[o]nce armed with the fourteenth amendment, corporations wielded it with considerable force." 276 But we are not concerned with the twentieth century evolution of corporations' constitutional rights. Rather, for the purposes of our originalist analysis, we are concerned with the rights that corporations were deemed to possess at the time of the ratification of the Fourteenth Amendment. The evidence indicates to us that even thirty and forty years after the enactment of the Amendment, the Court only extended limited property rights to corporations, sufficient to enable them to pursue their business. We are aware of no evidence from the case law that courts extended constitutional speech or political rights to corporations. ${ }^{277}$

270 Pembina Consol. Silver Mining \& Milling Co. v. Pennsylvania, 125 U.S. 181 (1888).

271 Minneapolis \& St. Louis Ry. Co. v. Beckwith, 129 U.S. 26 (1889).

272 Bloch \& Lamoreaux, supra note 1, at 17-18.

273203 U.S. 243 (1906). The Missouri statute is only one example of the "torrent" of statutes that states passed to regulate insurance companies and protect consumers. FrIEDMAN, supra note 100 , at 414 .

274 Riggs, 203 U.S. at 255.

275 Friedman, supra note 100, at 397.

276 Carl J. Mayer, Personalizing the Impersonal: Corporations and the Bill of Rights, 41 HasTINGS L.J. 577, 589 (1990).

277 The Court later extended speech rights to corporations, but in a way consistent with the Field rationale. In Grosjean v. American Press Co., Inc., 297 U.S. 233 (1936), the Court ruled that a newspaper could assert First Amendment rights. O'Kelley, supra note 9, at 1360 (" $[\mathrm{U}]$ nder the Field rationale, a corporation whose business includes publishing a newspaper must be able to assert first amendment rights of freedom of speech and press to protect its business."). In NAACP v. Alabama ex rel. Patterson, 357 U.S. 449 (1958), the Court held that the NAACP could assert its members' right to free association, and in NAACP v. Button, 371 U.S. 415 (1963), the Court held that the NAACP could itself assert First Amendment rights. But the NAACP was a nonprofit, advocacy organization, and this associational theory of constitutional rights made sense because "[ $t]$ he NAACP's membership was limited to those holding and desiring to express the same views." O'Kelley, supra note 9 , at 1364 . As we stated at the outset, our inquiry concerns business corporations. 


\section{Corporate Law Treatises}

Just as we examined treatises published before 1868 for evidence of whether corporations had the right to give money to support candidates for elected office, we also examine treatises published before 1900. These confirm that nothing had changed in the constitutional conception of the corporation.

In 1881, Platt Potter published his Treatise on the Law of Corporations. ${ }^{278}$ He adopted verbatim Chief Justice Marshall's "classic" and "practical" definition of the corporation: an "artificial being . . . possess[ing] only those properties which the charter of its creation confers upon it, either expressly, or as incidental to its very existence." 279 A corporation was so closely regulated that it was not permitted to support, directly or indirectly, an undertaking that might be beneficial to the corporation, without express authorization in its charter. ${ }^{280}$

Of considerable interest to us is Potter's discussion of a corporation's “citizenship." Consistent with the Court's holding in Paul v. Virginia, Potter observed that the Privileges and Immunities Clause of Article IV, Section 2, Clause 1 of the Constitution did not clothe corporations with the rights of natural persons:

The constitution of the United States provides, that the "citizens" of each state shall be entitled to all the privileges and immunities of the citizens of the several states; but it has been repeatedly held that, though corporations are "persons" for many purposes, they are not "citizens" within the foregoing provision of the constitution so as to entitle them to all the rights and privileges of natural persons. And it is also held that the term citizen, has different meanings in different parts of the same constitution. Indeed, it is held that corporations have no status even in the states creating them as citizens . . . .281

278 Platt Potter, Treatise on the Law of Corporations: General and Local, Public And Private, Aggregate and Sole (1879).

279 Id. at 4.

$280 I d$. at 51-52.

A corporation is not entitled, without express permission in the incorporating statute, to apply its corporate powers to the support of any undertaking which does not come within the purposes for which it was incorporated. It is not empowered to guarantee out of its corporate funds the payment of a dividend to parties carrying on such undertaking, although it may be calculated to increase the proper business of the corporation, and the majority of the corporators approve of such application of the corporate funds, and the object of the underId. taking be in no respect contrary to the public interests.

$281 I d$. at 355. Potter's statement that corporations could be citizens for some purposes of the Constitution referred to the diversity jurisdiction established by Article 3, Section 2, which provides that " $[\mathrm{t}]$ he judicial power shall extend to all Cases . . . between a State and Citizens of another state [and] between Citizens of different States." U.S. Const. art. III, $\S 2$; 1 PotTer, supra note 278, at 356 . 
Corporations were "of course" not entitled to exercise the rights of natural persons, Potter wrote, drawing a comparison between persons and corporations that is reminiscent of the Declaration of Independence: ${ }^{282}$

A citizen, in the strict and proper sense of [the Privileges and Immunities Clause of Article IV, Section 2], if a citizen of one state, is, for most purposes a citizen of all the states; and is entitled to all such privileges and immunities within the purview of the constitution as the citizens of those states permanently residing therein are entitled to. These are personal privileges, and attach to him in every state into which he may enter as a human being-as personal faculties, to appreciate and enjoy them as a man made in God's own image, as distinguished from that mainly technical, intangible, legal entity, an indivisible artificial being called a corporation. ${ }^{283}$

Potter next approvingly cited a decision from the Supreme Court of Illinois, affirmed by the United States Supreme Court, that corporations had no right to be involved in the political process:

As has been said, "the individual citizen has the power to move from place to place at his own volition, as business or pleasure may prompt him. He has rights which are so important as to make it desirable that they should be uniform throughout this broad expanded union; and which are needful in order to promote mutual friendship and free social or business intercourse among the people of the several states. These rights were placed by this clause of the constitution under the protection of the federal government. In the case of corporations, no such reasons exist. Corporations, even in the states of their own creation, are not entitled to all the rights and privileges of citizens of such states. They cannot vote at elections; they are ineligible to any public office; they cannot be executors, administrators or guardians; they are artificial beings endowed only with such powers and privileges and rights as their creator has thought proper to bestow upon them. They have not the power of locomotion, and of course are not fit subjects in the view above expressed of the constitutional clause cited."284

Also of interest to us is Potter's discussion of the rule of ultra vires. Although the doctrine of ultra vires was weakening by the end of the nineteenth century, Potter considered that the rule had been "recently introduced" into the United States, and was of great interest because of " $[\mathrm{t}] \mathrm{he}$ great number of these [corporations], the vast interests of the people coming within their control; the numerous novel questions arising out of their transactions; and the mighty power wielded by them for good or evil." 285 Potter allowed that the doctrine was not always clear in its application. ${ }^{286}$ But he regarded it as being of critical importance in restraining the power of corpo-

\footnotetext{
282 See supra text accompanying note 87.

2831 Potтer, supra note 278, at 356.

284 Id. (quoting Ducat v. City of Chicago, 48 Ill. 172, 180 (1868), aff'd, 77 U.S. (10

Wall.) 410 (1870)).

2852 PоттеR, supra note 278 , at $652-53$.

$286 I d$. at 653.
} 
rations, which were "often influencing, and sometimes even overshadowing the power and policy of the government itself."287

Corporate law in the academy was not static in this time. Victor Morawetz, in his Law of Private Corporations in 1882, "proposed a radical reinterpretation of the legal status of the corporation."288 In Morawetz's nontraditional view, a corporation was akin to a partnership; 289 a corporation's charter was a contract among the stockholders, not between the stockholders and the state. ${ }^{290}$ But Morawetz's associational view of the corporation did not lead him to ascribe greater rights to it than other writers. The state could reserve to itself the right to alter or repeal the charter in its general incorporation law. ${ }^{291}$ Furthermore, the state could regulate the corporation's activities with general legislation, such as laws preventing nuisance, regulations on companies "affecting the public interest" (such as railroads), and tax laws, ${ }^{292}$ as well as special legislation affecting only individual corporations. ${ }^{293}$ Morawetz acknowledged that there were constitutional limits on a state's ability to interfere with corporations, but, much like Justice Field, noted that these limits only prevented infringement of corporations' contractual or property rights. ${ }^{294}$ For example, a state could not confiscate the property owned by the stockholders in corporate form. ${ }^{295}$ But, again, there is no inkling that the state was without the power to regulate a business corporation's

287 Id. As he wrote:

This view of the powers and influence of corporate bodies, presents the necessity of the existence in our jurisprudence of the exercise of legal safeguards for the government and the people; this can now be exercised in the administration of the principles of law under that feature of it called ultra vires.

Id. Potter also noted that the doctrine of ultra vires stemmed from the Dartmouth College conception of the corporation as one that "possesse[d] only those properties which the charter confers upon it either expressly or as incidental to its very existence." Id. at $652 \mathrm{n} .2$ (quoting Trs. of Dartmouth Coll. v. Woodward, 17 U.S. (4 Wheat.) 518, 636 (1819)).

288 Horwitz, supra note 88, at 203.

289 Id.

2902 Victor Morawetz, The Law of Private Corporations $§ \S 1045-47$, at 1002-08 (2d ed. 1886).

$291 I d$. $\$ 1095$, at 1057 ("When the legislature enacts a charter or general incorporation law containing a reservation of the power of alteration, it in effect authorizes the formation of a corporation only on condition that the shareholders shall consent that the State may exercise such control over the company as the power of alteration implies; and the persons forming a corporation under such a charter or law must be held to assent to this condition, and voluntarily to confer the power upon the State."). The idea of a state reserving to itself the power of altering the rights granted in a charter can be traced to Justice Story's concurring opinion in Dartmouth College. Trs. of Dartmouth Coll. v. Woodward, 17 U.S. (4 Wheat.) 518, 712 (1819) (Story, J., concurring).

2922 Morawetz, supra note $290, \S \S 1061-75$, at 1022-38.

293 Id. § 1080, at 1042-43.

$294 I d . \S 1063$, at 1023 ("[A]ll the important constitutional provisions regarding property and contract rights apply to persons under all circumstances, and therefore to persons who have formed a corporate association.").

295 Id. $\S 1104$, at 1067. 
involvement in the political process, or that any corporation possessed any right to act on that process.

Any mention of a corporation's right to become involved in the political process is also lacking from William Cook's treatise on corporate law, updated in a third edition in 1894 and "widely used around the turn of the century." 296 Cook's treatise was thoroughly modern: he discusses the legal treatment of derivatives such as puts, calls, and straddles. ${ }^{297}$ But he nevertheless defines a corporation in the same way as Chief Justice Marshall: " $[\mathrm{A}] \mathrm{n}$ artificial being, invisible, intangible, and existing only in contemplation of law."298

Cook acknowledged that corporate law was relaxing its restrictions on corporations: the theory that a private corporation has no powers other than those expressly given or necessarily implied "is no longer strictly applied." 299 This is because a stockholder retained the right to object to the corporation's acts, which might otherwise be ultra vires and illegal, and the state had no need or desire to interfere in the affairs of a private corporation. ${ }^{300}$ But a state could still step in and limit the implied powers of a corporation when public policy so required, such as when corporations did, in their corporate capacity, things only humans could do individually. ${ }^{301}$

A state could also amend a corporate charter, when doing so was in the public interest. ${ }^{302}$ Likewise, a state could repeal a charter under quo warranto or scire facias, for example where the corporation had failed to use its corporate privileges. ${ }^{303}$ But Cook also noted that states were now competing for charters: where one state was "hostile or unduly restrictive or exacting in its requirements from corporations .... [t] he charters are taken out elsewhere." 304 Cook noted that New Jersey was the favored destination of these corporations: it permitted incorporation "for any lawful business or purpose whatever," and had attracted large numbers of corporations from New York. ${ }^{305}$

296 Adam Winkler, Corporate Law or the Law of Business?: Stakeholders and Corporate Governance at the End of History, 67 Law \& Contemp. Probs. 109, 112 (2004) (referring to William W. Cook, A Treatise on Stock and Stockholders, Bonds, Mortgages, and General Corporation Law (3d ed. 1894)).

2971 Соок, supra note 296, ch. XX, § 344, at 472.

298 Id. ch. I, § 1, at 1-2 (quoting Trs. of Dartmouth Coll. v. Woodward, 17 U.S. (4 Wheat.) 518, $636(1819))$.

299 Id. ch. I, § 3, at 5.

$300 I d$.

$301 I d$. (as a matter of public policy, railroads did not have the implied powers to sell property just as individuals might); see also 2 Cook, supra note 296, ch. XL, $\$ 681$, at 971-73 (same); cf. State ex rel. Att'y Gen. v. Standard Oil Co., 30 N.E. 279 (Ohio 1892) (the Standard Oil Company was not permitted to transfer its property to a trust, even though the individual stockholders would have been permitted to).

3021 CоOK, supra note 296, ch. XXVIII, $\$ 501$, at 634-35.

303 Id. ch. XXXVIII, § 635, at 869-70.

3042 Cook, supra note 296, ch. LVI, § 934, at 1603.

305 Id. ch. LVI, § 935, at 1604 (citations omitted). 
But as we discussed earlier, just as incorporation statutes became more liberal toward the end of the nineteenth century, other sources of regulation arose to take their place. ${ }^{306}$ We discuss these twin phenomena next.

\section{The Further Growth of External Regulation}

State and federal regulation bloomed after the Civil War. ${ }^{307}$ The main object of regulation was still the railroads; state railroad commissions, largely toothless before 1860 , finally acquired the power to fix railroad rates. ${ }^{308}$ The Wisconsin Supreme Court upheld the power of that state to fix railroad rates in 1874, noting that "such aggregations of capital and power, outside of public control, are dangerous to public and private right; and are practically above many public restraints of the common law." 309 Insurance and banking were also increasingly regulated in this period. By 1905, twenty-two of the then-forty-five states of the union had insurance commissions, up from twelve in 1873. ${ }^{310}$ Public health laws, which affected businesses producing food and drugs, were passed in growing numbers. ${ }^{311}$ At the state and local level, regulation also grew: American Bar Association reports from the final quarter of the century contain law after law on business practices, labor relations, and employment conditions. ${ }^{312}$ Another scholar has described American economic life in the nineteenth century as being under a "deluge" of local and state restrictions. ${ }^{313}$

But the main restrictions on business corporations were federal. To remedy the inability of individual states to regulate interstate commerce, in 1887 Congress established the Interstate Commerce Commission, the first federal independent regulatory commission. ${ }^{314}$ In 1890, Congress enacted the Sherman Antitrust Act, ${ }^{315}$ which became an effective weapon against

306 See supra Section V.C.

307 In a thorough review of how corporations attempted to use the Bill of Rights to advance their interests, Professor Mayer links the rise of externality regulation of the increasingly powerful corporations that arose after the move to general corporation laws to corporate interest in using the Constitution to restrict regulation of their activities. Mayer, supra note 276 . As he notes, when corporations were specifically chartered by government, their activities were restricted in their charters, minimizing the need for more general prudential regulation. Id. at 584. After specific chartering gave way to authorizing the formation of corporations under more enabling general corporation statutes, substantive legislation regulation externality risks created by corporate activity became common, and corporations used constitutional litigation to attempt to invalidate or limit regulation. Id. at 662 n.365.

308 Friedman, supra note 100, at 334-37.

309 Att'y Gen. v. Chi. N.W. Ry. Co., 35 Wis. 425, 530 (1874).

310 Friedman, supra note 100 , at 332.

$311 I d$. at 345.

$312 I d$. at 332.

313 William J. Novak, The People's Welfare 84 (1996).

314 See Robert L. Rabin, Federal Regulation in Historical Perspective, 38 Stan. L. Rev. 1189, 1206, 1216 (1986).

31526 Stat. 209 (1890), codified at 15 U.S.C. $\$ \S 1-7$ (2012). 
trusts, where state antitrust laws had failed. ${ }^{316}$ In the antitrust field, "the big antitrust authority was federal," not state. ${ }^{317}$ After the enactment of the Sherman Act, the growth of federal regulation continued with the Transportation Act of 1920 and, later, the regulatory statutes of the New Deal. ${ }^{318}$ And even during the so-called Lochner era, when courts invalidated social and economic legislation on due process grounds, states' ability to regulate their corporations "was and remained expansive." 319

It was in the midst of this flowering of regulation that New Jersey passed its liberal general incorporation law. This statute was the brainchild of a New York lawyer, James Dill, who in 1890 persuaded New Jersey's governor that by loosening the restrictions on corporations New Jersey could attract corporations from New York. ${ }^{320}$ Dill himself disputed that capital flooded into New Jersey because that state had liberalized its laws; rather, he ascribed New Jersey's success to the stability and evenhandedness of its law, the ability of its executive officers, and the quality of its judges and bar. ${ }^{321}$ Dill further argued that other states had erroneously "adopt[ed] the utility provisions of New Jersey's laws without the elements of control and regulation, which latter are an essential and permanent part of her system." ${ }^{22}$ But Dill was so conscious of the need for regulation of corporations that he proposed a system of federal incorporation, so that companies could not evade one state's requirements by reincorporating in another state. ${ }^{323}$

Dill did not get his wish for federal chartering. And in 1912, Woodrow Wilson, as governor of New Jersey, urged the state legislature to reform the liberal incorporation statute by preventing corporations from holding other companies' stock-in essence, prohibiting holding companies. ${ }^{324}$ New Jersey corporations relocated to Delaware, which had updated its corporation law in 1899 to create a more inviting legal regime. ${ }^{325}$

But the old internal restraints on corporations were not abandoned completely. As we have noted, corporate law continued to give strong protections to stockholders by, for example, requiring them to unanimously approve any extraordinary transaction, much stronger regulation of corpo-

316 For example, Ohio and Texas attempted to break up the Standard Oil Company, but failed. Friedman, supra note 100, at 347. The Department of Justice later succeeded. Standard Oil Co. of N.J. v. United States, 221 U.S. 1 (1911).

317 Mark J. Roe, Delaware's Competition, 117 Harv. L. Rev. 588, 610 (2003).

318 Rabin, supra note 314, at 1240.

319 Matthew J. Lindsay, In Search of "Laissez-Faire Constitutionalism", 123 Harv. L. REv. Forum 55, 66 (2010).

320 See Melvin I. Urofsky, Proposed Federal Incorporation in the Progressive Era, 26 Ам. J. Legal Hist. 160, 163-64 (1982).

321 James B. Dill, National Incorporation Laws for Trusts, 11 YALE L.J. 273, 281 (1902).

$322 I d$.

$323 I d$. at 274 ("The country demands uniform corporate legislation, formulated upon the good of the country as a whole, and not sectional legislation, state against state.”).

324 Roe, supra note 317 , at 610 .

325 Id. at $609-10,610$ n.69. 
rate means than was contained in McCain-Feingold. ${ }^{326}$ And the ultra vires doctrine continued to hold sway in the late nineteenth century as the predominant legal rule, although, as noted, it was weakening. ${ }^{327}$ In his 1897 treatise, Reuben Reese reiterated the orthodox doctrine that a corporation, "[c]reated by the state ... has such powers as the state has seen fit to give itonly this and nothing more." 328 Therefore, any act that was not sanctioned by a corporation's charter was a nullity. ${ }^{329}$ Reese's view was, as he admitted, conservative and out of step with "some modern law writers." 330 Nevertheless, ultra vires remained an important consideration throughout the nineteenth century and into the twentieth. ${ }^{331}$ As late as 1915 , corporations were not allowed to donate money to charitable organizations, even if the donation might ultimately benefit the corporation. ${ }^{332}$ And, of particular interest to our inquiry, at least two courts shortly after 1900 ruled that political donations made by managers and directors were ultra vires. ${ }^{333}$

These applications of the ultra vires doctrine, together with the everincreasing growth of external regulation of corporations, cast doubt on the assertion that the government was without power after the enactment of the Fourteenth Amendment to prevent a corporation from involving itself in the political process, much less to regulate, as per McCain-Feingold, the means by which it could do so. To the contrary, we draw the conclusion that government could comprehensively control a corporation's activities, with the sole limitation that it could not unconstitutionally interfere with the corporation's property rights. As a final piece of evidence, we now conduct a brief histori-

326 See supra note 209; see, e.g., Geddes v. Anaconda Copper Mining Co., 254 U.S. 590, 596 (1921) ("[A] majority of the stock may not authorize the sale of all of the property of a going and not unprofitable company, [because] ... such power would defeat the implied contract among the stockholders to pursue the purpose for which it was chartered.").

327 See Friedman, supra note 100, at 395-96; Hovenkamp, supra note 135, at 1665. The writ of quo warranto, by contrast, fell into disuse. Hurst, supra note 16, at 161 .

328 Reuben A. Reese, The True Doctrine of Ultra Vires in the Law of Corporations $\S 19$, at 29 (1897).

$329 I d$.

330 Id. at v; see also Walter C. Douglas, Jr., The True Doctrine of Ultra Vires, 45 Am. L. REG. 414, 414 (1897) (book review).

331 See generally Clyde L. Colson, The Doctrine of Ultra Vires in United States Supreme Court Decisions, 42 W. VA. L. Q. 179 (1936); see also Cent. Transp. Co. v. Pullman's Palace Car Co., 139 U.S. 24, 53 (1891) (the appellant's contract to transfer its railway car manufacturing business to the appellee was void under the doctrine of ultra vires, and, independently, void because it worked an unreasonable restraint of trade).

332 See, e.g., Brinson Ry. Co. v. Exch. Bank of Springfield, 85 S.E. 634, 635 (Ga. Ct. App. 1915).

333 See McConnell v. Combination Mining \& Milling Co., 76 P. 194, 199 (Mont. 1904) ("[Political contributions] were clearly outside of the purposes for which the corporation was created ....."); People ex rel. Perkins v. Moss, 80 N.E. 383, 387 (N.Y. 1907) ("The company had not the right, under the law of its existence, to agree to make contributions for political campaigns, any more than to agree to do other things foreign to its charter ...."). 
cal survey of campaign finance laws-the type of law that was struck down in Citizens United.

\section{E. Campaign Finance Laws}

The period after the turn of the twentieth century saw the enactment of the first campaign finance laws-motivated, as Professor Briffault has noted, to ward off the "particular danger of "corrupting the elector and debauching the election." "334 Reform was motivated by concerns about the influence powerful corporations had over government, as well as concerns about corporate officers misusing funds to further their own interests. ${ }^{335}$ Prominent politicians such as Theodore Roosevelt and Elihu Root called for regulation of corporate involvement in politics. In President Roosevelt's 1905 Congressional address, he stated:

All contributions by corporations to any political committee or for any political purpose should be forbidden by law; directors should not be permitted to use stockholders' money for such purposes; and, moreover, a prohibition of this kind would be, as far as it went, an effective method of stopping the evils aimed at in corrupt practices acts. Not only should both the National and the several State legislatures forbid any officer of a corporation from using the money of the corporation in or about any election, but they should also forbid such use of money in connection with any legislation save by the employment of counsel in public manner for distinctly legal services. ${ }^{336}$

Elihu Root similarly observed in an 1894 address:

The use of money . . a at the hands of both of the great political parties in this country that we find enormous contributions necessary to maintain party machinery, to conduct party warfare . . . [T] he effect is that great moneyed interests, corporate and personal, are exerting yearly more and more undue influence in political affairs. . . . [P]olitical parties are every year contracting greater debts to the men who can furnish the money to perform the necessary functions of party warfare. The object of this amendment is, by laying down a simple rule, to put an end, if possible, to that great crying evil of American politics. ${ }^{337}$

Two of the statutes resulting from this political momentum were the federal Tillman Act and Montana's Corrupt Practices Act. These laws, of course, postdate the Fourteenth Amendment by forty years, but their enactors were still far closer in time to the ratification of the Fourteenth Amendment than

334 See Richard Briffault, The Uncertain Future of the Corporate Contribution Ban, 49 VAL. U. L. Rev. 397, 407 (2015) (quoting United States v. U.S. Brewers' Ass'n, 239 F. 163, 169 (W.D. Pa. 1916)).

335 Id. at 404-06.

336 Theodore Roosevelt, Message Communicated to the Two Houses of Congress at the Beginning of the First Session of the Fifty-Ninth Congress (Dec. 5, 1905), in 4 Presidential Addresses and State Papers 560, 595 (1910).

337 Elihu Root, The Political Use of Money (Sept. 3, 1894), in Addresses on Government And Citizenship 141, 143 (Robert Bacon \& James Brown Scott eds., 1916). 
we are now. ${ }^{338}$ We focus on these two in particular because the Tillman Act is the first federal law addressing corporate political spending, and the constitutionality of the Montana act was litigated post-Citizens United.

The Tillman Act prevented corporations from giving direct contributions to federal candidates or their campaigns. ${ }^{339}$ The aim of the Tillman Act was to reduce corruption and the perception of corruption. ${ }^{340}$ Another purpose was to prevent the managers of firms from spending stockholders' money in ways that the stockholders would not approve. ${ }^{341}$

The Tillman Act was challenged as unconstitutional in federal court by a group of brewing corporations that were indicted for making contributions to federal elections. ${ }^{342}$ In upholding the constitutionality of the Act, Judge Thomson echoed Chief Justice Marshall's Dartmouth College decision and accepted as still good law that corporations are creatures of law that exist solely to advance the public welfare:

In the exercise of its prerogatives and to secure greater economy and efficiency, the government has thought best that certain artificial bodies should be created with certain fixed and definite powers; and acting within certain prescribed limitations. These artificial creatures are not citizens of the United States, and, so far as the franchise is concerned, must at all times be held subservient and subordinate to the government and the citizenship of which it is composed. ${ }^{343}$

Nor was the court troubled by the First Amendment challenge: the challenged Act "neither prevents, nor purports to prohibit, the freedom of speech or of the press. Its purpose is to guard elections from corruption, and the electorate from corrupting influences in arriving at their choice." 344 There is no record of an appeal of this decision, and members of Congress

338 These laws were not the first; that distinction belongs to Kentucky, which amended its constitution in 1891 to ban the use of corporate funds to influence any election. Adam Winkler, "Other People's Money": Corporations, Agency Costs, and Campaign Finance Law, 92 Geo. L.J. 871, 883 (2004) (citing Ky. Const. § 150 (1891)).

339 Tillman Act of 1907, ch. 420, 34 Stat. 864 (codified as amended at 2 U.S.C. $\S 441 \mathrm{~b}(\mathrm{a})(2012))$.

340 S. REP. No. 59-3056, at 2 (1906) ("[The ban on corporate contributions] is in the interest of good government and calculated to promote purity in the selection of public officials.”).

34141 Cong. Rec. 22 (1906); 40 Cong. Rec. 96 (1905); Winkler, supra note 338, at 912-13 (noting that the Tillman Act's main purpose was to protect stockholders by preventing managers from misspending their money).

342 United States v. U.S. Brewers' Ass'n, 239 F. 163 (W.D. Pa. 1916).

$343 I d$. at 168. The court concluded that obviously Congress could restrict the right of federally chartered corporations and national banks to make political contributions. The court spent slightly longer on the question of whether Congress could restrict the ability of state chartered corporations to make political contributions, but still concluded, with little trouble, that Congress had the power to regulate its own elections.

$344 I d$. at 169. As Professor Briffault has noted, "[b]efore the 1940s, the First Amendment played little role in the judicial assessment of campaign finance restrictions." Briffault, supra note 334 , at 407. 
had only a very faint concern, if any, that the Tillman Act might be unconstitutional. ${ }^{345}$

Montana's Corrupt Practices Act was enacted in 1912. ${ }^{346}$ The first section of the statute provided that "[a] corporation may not make a contribution or an expenditure in connection with a candidate or a political committee that supports or opposes a candidate or a political party." 347 The law was enacted by a popular initiative in response to scandals caused by the domination of Montana's economy by copper interests. In 1889, two "copper kings," William Clark and Marcus Daly, attempted to bribe voters to vote for their choice of seat for the state capital. ${ }^{348}$ In 1899, Clark bribed the state legislature to elect him to the U.S. Senate. ${ }^{349}$ In the early years of the twentieth century, a third copper king, Augustus Heinze, "bought" two trial judges in Butte and so secured favorable rulings in his legal battles with the Amalgamated Copper Company. ${ }^{350}$ In 1903, the Amalgamated Copper Company showed its political clout by, in response to two court rulings against it, shutting down its mining operations and putting four-fifths of the Montana labor force out of work. ${ }^{351}$ The Company suffered such a backlash that it reduced its political involvement and in 1906 the Montanan voters amended their constitution to permit voter-sponsored ballot initiatives-i.e., legislation enacted without the potentially corrupt intermediary of the state legislature. ${ }^{352}$

But the Amalgamated Copper Company could not stay out of Montanan politics for long, and in the 1909 legislative session sponsored an amendment to the state's general incorporation law that would allow it to control other businesses. $^{353}$ In 1910, the Company tried to ensure that the Republican Party won a majority in the state legislature, and in 1911, the Company prevented the Democrats in the legislature from electing their chosen candidate as U.S. Senator and from enacting a direct primary law. ${ }^{354}$ Finally, through an initiative process (because the legislature was corrupt), the state's frustrated voters passed the Corrupt Practices Act to blunt the Amalgamated Copper Company's influence on state politics.

This restriction on political spending in Montana remained intact for over six decades. ${ }^{355}$ It therefore seems to us contrary to our history to argue

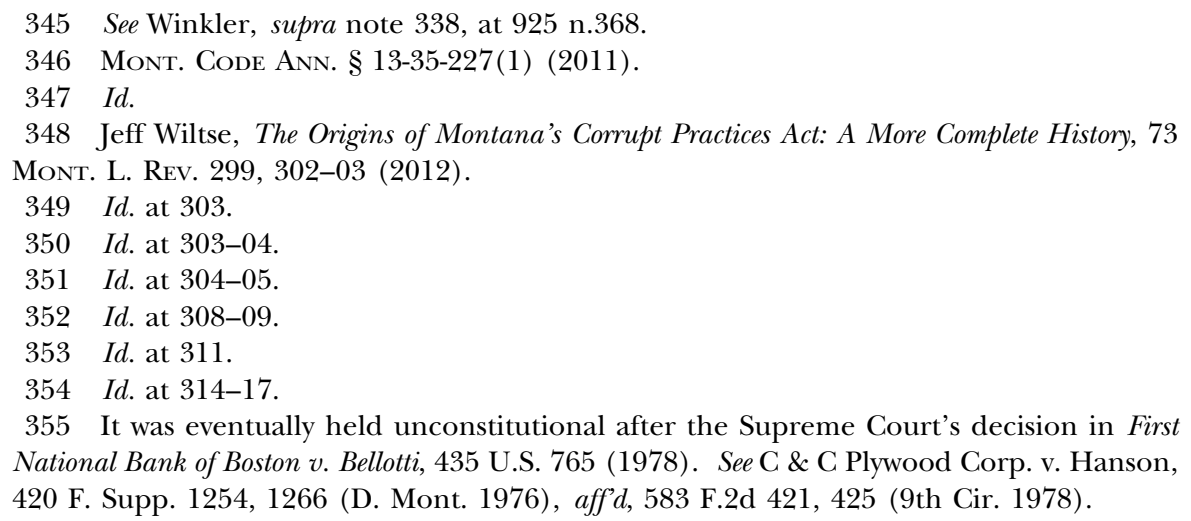


that the Constitution has always been understood to grant the same speech rights to corporations as human beings, or that corporations have always been understood to have a constitutionally protected right to spend treasury funds on political campaigns. Rather, the opposite appears to be the case. As the Supreme Court of Michigan held in a 1916 case upholding the conviction of a director of a brewing company that had donated $\$ 500$ in a referendum campaign against a local dry law: "The expenditure of the money of the Lansing Brewing Company for election purposes cannot be deemed to be a property right within the meaning of the Fourteenth Amendment. Such corporations have no right to participate in the elective franchise." ${ }^{556}$

Into the twentieth century, the predominant view of the corporation's relation to society remained as it had been. The corporation was still largely seen as an entity that only possessed what rights it was given, with the limited extension to wield those constitutional rights closely associated with the property rights of its members. Although the ultra vires doctrine was in a weaker form, it remained potent to police attempts by corporate managers to engage in activities not closely related to its business, including political contributions. Moreover, as soon as general corporation statutes emerged and the internal constraints of corporate law, charters, and the ultra vires doctrine began to loosen, external regulation of the corporation emerged without any suggestion that corporations could object to that regulation.

\section{Originalism and Campaign Finance Restrictions}

We doubt the utility of interpreting the Constitution using the originalist method advocated by Justice Scalia. We tend to believe it does little to provide results that can be defended as the neutral product of ideologically free reasoning. Because judges are not historians, public understandings of terms are themselves often disputed, and society (and its legislatures) acts in reliance on interpretations made by prior generations, we are not confident that any decision of the Court in 2015 can truly be driven by an accurate understanding of the public meaning of the Constitution in 1791 and $1868 .{ }^{357}$ But we acknowledge that reasonable minds can and do differ on this subject, and we have attempted to apply the originalist method that the concurring originalists adhere to faithfully. When we do so, we conclude that the method cannot justify the result in Citizens United. This is true whether we only look at the ratification of the First Amendment in 1791, as Justice Scalia did, or whether we look also at the ratification of the Fourteenth Amendment in 1868. In fact, if an originalist approach is taken, the result in Citizens United is harder, not easier to sustain.

356 People v. Gansley, 158 N.W. 195, 200 (Mich. 1916). The Michigan Supreme Court also rejected the brewing company's argument on the basis of the free speech clause of the Michigan Constitution. Id. at 201. Although the court was equally divided, the dissent did not challenge the court's constitutional analysis, and only disagreed that the statute was not designed to cover this kind of referendum. Id. at 201-02 (Brooke, J., dissenting).

357 See supra notes 21 and 65. 
Despite Justice Scalia's words to the contrary, there is abundant evidence that legislatures could restrict corporations' ability to act on the public political process at the time of the Founding and at the time of the enactment of the Fourteenth Amendment. It is difficult to ignore Chief Justice Marshall's understanding that corporations had only such rights as the legislature gave them, especially when that widely cited understanding remained good law well into the twentieth century. If anything, our conclusion is understated because the historical reality is that the public and jurists readily accepted that the state had the ability to regulate corporations. ${ }^{358}$ It was unthinkable in the mid-nineteenth century, as it was at the time of the Founding, that the legislature should not be able to regulate corporations as it saw fit.

Therefore, it is not surprising that the Supreme Court's willingness to permit corporations to wield constitutional rights was selective and inconsistent throughout the early twentieth century. But as a general matter, the Court was reluctant to allow corporations to assert rights that were deemed personal in nature. It is true that in certain Plessy-era rulings ${ }^{359}$ the Supreme Court made blanket statements to the effect that it was already "well settled that corporations are persons within the provisions of the Fourteenth Amendment of the Constitution of the United States."360 But those statements merely echoed the unexplained holding to that effect in Santa Clara, ${ }^{361}$ and the cases that the Court cited in support of those statements reflected the nuanced rationale of Justice Field that we have discussed above. ${ }^{362}$

And the Court did not ascribe to the view that corporations were the same as human persons in all or even most cases. Although in many instances, the Court held that corporations could be considered "persons" under the Fourteenth Amendment and invoke rights granted by specific amendments in the Bill of Rights (as incorporated against the states by the Fourteenth Amendment), that was not invariably the case. Thus, the Supreme Court, on the one hand, held that corporations are persons for purposes of (i) the Fifth Amendment right to be free from double jeop-

358 Hurst, supra note 16, at 113 ("[L]itigants accepted legislative chartering authority and by failure to press the issue on the courts reflected pervasive community acceptance of the legitimacy of legislative determinations as to how far the corporate device should be used.").

359 Plessy v. Ferguson, 163 U.S. 537 (1896).

360 Gulf, Colo. \& Santa Fe Ry. Co. v. Ellis, 165 U.S. 150, 154 (1897); see also, e.g., Covington \& Lexington Tpk. Rd. Co. v. Sandford, 164 U.S. 578, 592 (1896) ("It is now settled that corporations are persons within the meaning of the constitutional provisions forbidding the deprivation of property without due process of law, as well as a denial of the equal protection of the laws.").

361 Santa Clara Cty. v. S. Pac. R.R. Co., 118 U.S. 394, 396 (1886).

362 E.g., Minneapolis \& St. Louis Ry. Co. v. Beckwith, 129 U.S. 26, 28 (1889), cited in Ellis, 165 U.S. at 154, and Sandford, 164 U.S. at 592; Pembina Consol. Silver Mining \& Milling Co. v. Pennsylvania, 125 U.S. 181, 187, 189 (1888), cited in Ellis, 165 U.S. at 154, and Sandford, 164 U.S. at 592; see supra Section VI.B. 
ardy; ${ }^{363}$ (ii) the Seventh Amendment right to trial by jury; ${ }^{364}$ and (iii) the Fourth Amendment right against unreasonable searches and seizures. ${ }^{365}$ But the Supreme Court has also held that (i) corporations are not persons for purposes of the right to liberty under the Fourteenth Amendment; ${ }^{366}$ (ii) the Fifth Amendment right against self-incrimination does not apply to corporations; ${ }^{367}$ and (iii) corporations do not enjoy the same right to privacy as natural persons for purposes of the Fourth Amendment. ${ }^{368}$

As important, modern First Amendment law itself did not emerge until the 1920 s and ' 30 s, as virtually all scholars acknowledge. ${ }^{369}$ For example, at the time of Santa Clara, First Amendment jurisprudence itself was relatively unevolved. ${ }^{370}$ In 1907, Justice Holmes wrote that "the main purpose of such constitutional provisions [as the First Amendment] is 'to prevent all such previous restraints upon publications as had been practiced by other governments,' and they do not prevent the subsequent punishment of such as may be deemed contrary to the public welfare." ${ }^{371}$ In 1919, in Schenck v. United States, Holmes adopted the "clear and present danger" test, holding that Congress could criminalize certain speech in times of war. ${ }^{372}$ Only after extended communications with Judge Learned Hand did Justice Holmes write his famous dissent in Abrams $v$. United States, in which he argued that "the best test of truth is the power of the thought to get itself accepted in the competition of the market. . . That at any rate is the theory of our Constitution." 373

363 United States v. Martin Linen Supply Co., 430 U.S. 564, 576 (1977). We take this and the following examples from Professor Mayer's work, see supra note 276.

364 Armour Packing Co. v. United States, 209 U.S. 56, 76-77 (1908).

365 Hale v. Henkel, 201 U.S. 43, 71 (1906).

366 Nw. Nat'l Life Ins. Co. v. Riggs, 203 U.S. 243, 255 (1906) ("The liberty referred to in [the Fourteenth] Amendment is the liberty of natural, not artificial persons."); see also infra note 374 and accompanying text. But see First Nat'l Bank of Bos. v. Bellotti, 435 U.S. 765, 778-79 (1978) (rejecting as "untenable" the argument that a corporation's First Amendment rights must stem from its property rights under the Fourteenth Amendment).

367 Hale, 201 U.S. at 57-58.

368 Cal. Bankers Ass'n v. Shultz, 416 U.S. 21, 65-66 (1974).

369 See, e.g., David L. Hudson, Jr., The First Amendment: Freedom of Speech § 1:5 (2012); Thomas I. Emerson, Toward a General Theory of the First Amendment, 72 YALE L.J. 877, 877 (1963).

370 Santa Clara Cty. v. S. Pac. R.R. Co., 118 U.S. 394 (1886); see generally Thomas Healy, The Great Dissent: How Oliver Wendell Holmes Changed His Mind-and Changed the History of Free Speech in America (2013).

371 Patterson v. Colorado ex rel. Att'y Gen., 205 U.S. 454, 462 (1907) (quoting Commonwealth v. Blanding, 20 Mass. (3 Pick.) 304, 313-14 (1825)). This was the Blackstonian view. 4 William Blackstone, Commentaries $* 151$ ("The liberty of the press is indeed essential to the nature of a free state: but this consists in laying no previous restraints upon publications, and not in freedom from censure for criminal matter when published.").

372 Schenck v. United States, 249 U.S. 47, 52 (1919).

373 Abrams v. United States, 250 U.S. 616, 630 (1919) (Holmes, J., dissenting); see Gerald Gunther, Learned Hand and the Origins of Modern First Amendment Doctrine: Some Fragments of History, 27 Stan. L. Rev. 719, 732-33 (1975) (discussing Learned Hand's influence on Holmes). 
Accordingly, the Court meandered as it grappled with how much protection the First Amendment gave corporations in terms of the right to speak on the same terms as human persons. At some times, the Court seems to have applied the Field rationale: when the speech of a corporation was integrally related to its business function, that speech was protected. ${ }^{374}$ At others, it held that First Amendment rights were personal ones that could not be claimed by a corporation or labor union. ${ }^{375}$ Commercial speech was at times given more limited protection than other speech because it was economic in nature. ${ }^{376}$

Aside from the lack of a coherent rationale for these erratic rulings, what is most striking is how they generally did not address the mundane and accepted reality that as of the time of the adoption of the First Amendment and the Fourteenth Amendment, corporations were understood to be creatures of the state that could only undertake those activities that government permitted. ${ }^{377}$ But it is easy to conceive that the Court might conclude that when states authorized corporations, they were not subjecting those corpora-

374 See O'Kelley, supra note 9, at 1359-60 (discussing Grosjean v. Am. Press Co., 297 U.S. 233 (1936)); see also Pierce v. Soc'y of Sisters, 268 U.S. 510, 535 (1925). Pierce applied the Field rationale to the holding of Riggs: "Appellees are corporations and therefore, it is said, they cannot claim for themselves the liberty which the Fourteenth Amendment guarantees. Accepted in the proper sense, this is true. But they have business and property for which they claim protection.” Id. (citing Nw. Nat'l Life Ins. Co. v. Riggs, 203 U.S. 243, 255 (1906)).

375 Hague v. Comm. for Indus. Org., 307 U.S. 496, 514 (1939). Hague concerned the constitutionality of certain municipal ordinances that prohibited the leasing of any venues to subversive organizations without a permit and banned the distribution of pamphlets on the streets. $I d$. at 501. Justice Owen Roberts held that only the individual, and not the corporate, plaintiff-respondents had standing to challenge the ordinances on the ground that they abridged their right peaceably to assemble and engage in debate. Id. at 512-14. "Natural persons, and they alone, are entitled to the privileges and immunities which $\S 1$ of the Fourteenth Amendment secures for 'citizens of the United States.' I Id. at 514 (quoting U.S. Const. amend. XIV, § 1). Justice Roberts asserted that "it is clear that the right peaceably to assemble and to discuss these topics . . . is a privilege inherent in citizenship of the United States which the Amendment protects.” Id. at 512.

Justice Roberts was only joined by Chief Justice Hughes and Justice Black in this holding. Justice Stone, joined by Justice Reed, came to the same result, but observed that the Court in United States v. Cruikshank, 92 U.S. 542, 551-52 (1875), had held that the right to peaceable assembly was not secured against state action, and was not a "privilege and immunity" of citizens of the United States under the Fourteenth Amendment. Hague, 307 U.S. at 526. Therefore, Justice Stone rested his analysis on the Due Process Clause. Relying on Riggs, he held that "[a]s to the [corporate plaintiff], it cannot be said to be deprived of the civil rights of freedom of speech and of assembly, for the liberty guaranteed by the due process clause is the liberty of natural, not artificial, persons." Id. at 527 (citing Riggs, 203 U.S. at 255). Justices McReynolds and Butler dissented, and Justices Frankfurter and Douglas took no part in the decision.

376 Cent. Hudson Gas \& Elec. Corp. v. Pub. Serv. Comm'n, 447 U.S. 557, 561-63 (1980).

377 See supra Parts IV-VI. 
tions to expropriation of their assets without compensation. ${ }^{378}$ It is less easy to conceive of how the Court could conclude that the government could not restrict corporations from acting on the political process using the wealth they generated as a result in material part because of the special privileges given them by the legislatures who authorized their creation. To do so would clash directly with the understanding that corporations had only such rights as the society that created them chose to give them. ${ }^{379}$

Nor can evolution in academic theories of the firm justify Citizens United in originalist terms. Originalists would be the first to express dismay if the meaning of the law as of the time of enactment was determined by reference to later academic musings about the true nature of things. ${ }^{380}$ It may be, for example, that the for-profit corporation is best seen as a mere "nexus of contracts," 381 or as a distinct entity bringing together the firm-specific investments in a team of a variety of constituencies to be led by a board of directors as team leader (team production), ${ }^{382}$ or as an association formed by investors for mutual profit to be run on a direct democracy model, ${ }^{383}$ or a republican democratic model. ${ }^{384}$ These explanatory and normative perspectives may have their place in terms of influencing a policy debate within the political branches about where law should evolve by legislative enactment; they have no place in determining what the law meant as of 1791 and 1868, unless one of those theories was widely accepted and could be understood to serve as a contextual foundation for understanding the text of the First and Fourteenth Amendments.

As of the relevant time, the operative legal understanding was practical, not theoretical, and legislators understood themselves to be giving life to entities that had only such rights as the law gave them. Corporations were still in their nascent stage as institutions, general corporation statutes in particular were in their infancy, and corporations were understood as importantly distinct from humans and as permitted to engage only in those activities the positive law authorized. Whatever later theories said about

378 U.S. Const. amend. V; see, e.g., Monongahela Navigation Co. v. United States, 148 U.S. 312, 328 (1893).

379 See Trs. of Dartmouth Coll. v. Woodward, 17 U.S. (4 Wheat.) 518, 636 (1819) ("Being the mere creature of law, it possesses only those properties which the charter of its creation confers upon it, either expressly, or as incidental to its very existence.”).

380 E.g., Bork, supra note 26, at 187-235.

381 E.g., Michael C. Jensen \& William H. Meckling, Theory of the Firm: Managerial Behavior, Agency Costs and Ownership Structure, 3 J. FIN. Econ. 305, 310 (1976) (“[M]ost organizations are simply legal fictions which serve as a nexus for a set of contracting relationships among individuals." (emphasis omitted) (footnote omitted)).

382 E.g., Margaret M. Blair \& Lynn A. Stout, A Team Production Theory of Corporate Law, 85 VA. L. REv. 247, 249 (1999).

383 E.g., Lucian Arye Bebchuk, The Case for Increasing Shareholder Power, 118 HARv. L. REv. 833, 835 (2005).

384 E.g., Stephen M. Bainbridge, Director Primacy: The Means and Ends of Corporate Governance, 97 Nw. U. L. REv. 547, 550 (2003). 
them cannot alter the reality that it was understood that corporations owed their existence to law and were subject to its restrictions.

Thus, to explain the move to holding that the government cannot in fact limit the activities engaged in by corporations, it seems necessary to embrace the un-originalist notion that judicial glosses on the Constitution become part of the Constitution's meaning, and that that meaning evolves over time.

To this exact point, it was not until the Bicentennial year-1976-that the Supreme Court equated the ability to spend money with the ability to speak. ${ }^{385}$ In Buckley $v$. Valeo, the Court struck down the expenditure limit placed on candidates' campaigns by the Federal Election Campaign Act of 1976. The Court reasoned that a restriction on expenditures "necessarily reduces the quantity of expression," and the restriction in the Act $(\$ 1,000$ per candidate) was a "substantial ... restraint[ ] on the quantity and diversity of political speech." 386 By contrast, the Court upheld the Act's restriction on campaign contributions, because it entailed "only a marginal restriction upon the contributor's ability to engage in free communication." 387

And it was not until 1978 that there was a meaningful discussion by the Supreme Court of the extent to which corporations had First Amendment rights that were protected in the context of the political process. In First National Bank of Boston v. Bellotti, the Court relied on Buckley to hold that a Massachusetts law imposing criminal liability on corporations making expenditures on ballot initiatives was unconstitutional. ${ }^{388}$ Bellotti illustrates well how originalist reasoning does not easily support the invalidation of campaign finance restrictions. In dissent, Justice White, joined by Justices Brennan and Marshall, stressed the state's power to control its own corporations: states that restricted corporate political activity sought to prevent "institutions which have been permitted to amass wealth as a result of special advantages extended by the State for certain economic purposes from using that wealth to acquire an unfair advantage in the political process." 389 Or, more graphically: "The State need not permit its own creation to consume it." 390

Justice Rehnquist, dissenting separately, adopted the Field rationale. ${ }^{391}$ "There can be little doubt that when a State creates a corporation with the power to acquire and utilize property, it necessarily and implicitly guarantees that the corporation will not be deprived of that property absent due process

\footnotetext{
385 Buckley v. Valeo, 424 U.S. 1, 19 (1976) (per curiam).

386 Id. at 19.

387 Id. at $20-21$.

388435 U.S. $765,767-68,776$ (1978).

389 Id. at 809 (White, J., dissenting).

390 Id. The Bellotti majority replied that news corporations are able to participate in the political process and have a greater ability to dominate political debate than non-media corporations. Id. at 781 .

391 O'Kelley, supra note 9, at 1370 ("Justice Rehnquist, in dissent, was the only Justice to recognize the importance and true meaning of the cases underlying the Field rationale ....").
} 
of law."392 But, it does not follow that a corporation needs other constitutional protections to carry out its business. Justice Rehnquist wrote:

I can see no basis for concluding that the liberty of a corporation to engage in political activity with regard to matters having no material effect on its business is necessarily incidental to the purposes for which the Commonwealth permitted these corporations to be organized or admitted within its boundaries. ${ }^{393}$

There was no mention of originalism in Bellotti. ${ }^{394}$ But Justices White and Rehnquist grounded their reasons in actual historical understanding better than did the Bellotti majority or the concurring justices in Citizens United.

Given all the complexity that is involved in applying a constitution to new disputes in a constantly changing society, it is not surprising to us that current constitutional cases cannot be rationalized solely by current-day Justices based on the publicly understood meaning of the Constitution as of 1789 and 1868. Rather, cases like Citizens United are best explained by the reality that generations of intervening interpretations, when rendered in the context of real disputes arising in a changing society, have an effect on the meaning of the Constitution and how it applies in future cases. In other words, whether one finds favor with the holding in Citizens United or not, our only claim is that the outcome in the case is not one that can easily be rationalized by applying the originalist method of interpretation. To the contrary, the strong weight of the historical evidence would support the constitutional validity of Congress's right to regulate the corporation's involvement in the political process through the means set forth in McCainFeingold. As such, the decision in Citizens United to overturn a bipartisan statute appears to us more original than originalist.

392 Bellotti, 435 U.S. at 824 (Rehnquist, J., dissenting).

393 Id. at 828.

394 Despite originalism's name, it is a newfangled doctrine. See supra notes 20-21 and accompanying text; see also Posner, supra note 50, at 197. 